\title{
"Ehk nõiduseks tarvitatud" - maagilised esemed Eesti muuseumikogudes
}

\author{
Kristiina Johanson \\ Tartu Ülikooli ajaloo ja arheoloogia instituudi arheoloogia teadur \\ kristiina.johanson@ut.ee \\ Tõnno Jonuks \\ Eesti Kirjandusmuuseumi folkloristika osakonna vanemteadur \\ tonno@folklore.ee
}

\begin{abstract}
Teesid: Rahvapärase maagia uurimine on Eestis pika ajalooga. Juba sajandi eest hakati Eesti muuseumitesse koguma maagias kasutatud esemeid. Siiski puudub siiani ülevaade Eesti muuseumites hoitavatest maagilistest esemetest ning maagia materiaalsust kasutatakse üksnes illustratiivsetel eesmärkidel. Käesolevas artiklis anname ülevaate Eesti muuseumites leiduvatest maagilistest esemetest ning arutleme selle üle, miks ei ole füüsilisi esemeid haaratud maagia-teemalistesse uurimustesse.
\end{abstract}

Märksõnad: esemeuurimus, maagia, materia magica, muuseumikogud, ratsionaalsus

Kuigi maagia on paljudiskuteeritud nähtus, tegelevad sellega peamiselt folkloristid, antropoloogid ja religiooniloolased, keskendudes maagia narratiivsusele ja rituaalsusele. Suur osa maagilisi rituaale ja kontseptsioone on küll tihedalt seotud füüsiliste objektidega, kuid see valdkond on jäänud tagaplaanile ja narratiivse maagiakäsitluse puhul on maagilisi esemeid pigem eiratud või kasutatud üksnes illustratsioonidena. Selle tulemusena ei ole neid väärtustatud ka museoloogias ning kogudesse on need jõudnud kas juhuslikult või kuriositeetsete objektidena.

Maagilisi esemeid leidub maailma mastaabis peamiselt antropoloogiakogudes, kogutuna antropoloogide poolt retkedelt n-ö primitiivsete rahvaste juurde peamiselt koloniaaltaustaga maades (nt Pitt Riversi muuseum Oxfordis). Ilmselt ongi maagia tõlgendust kergem omistada kultuuriliselt, ajaliselt või ruumiliselt kaugematele "võõrastele" kui omadele. Näiteks on tähele pandud, et arheoloogilised uurimused maagia, religiooni, isiklike rituaalide ja neis kasutatavate 
esemete kohta USA-s on peamiselt keskendunud Aafrika diasporaale (Manning 2014: 2-3). Ühine nii Eestile kui ka laiemale Euroopa traditsioonile on aga maagilisi esemeid puudutavate akadeemiliste ja analüüsivate käsitluste vähesus kuni viimaste aastateni (Bremmer 2015). Osalt on see seotud maagia ambivalentsusega ja põhinemisega narratiivil, mistõttu on maagilisi esemeid raske klassifitseerida ja teaduslikult käsitleda. Seetõttu on ka akadeemilistes uurimustes maagiat käsitletud suuresti antiikmaailma tekstiliste korpuste (loitsud, ravikirjeldused jne) ja tekstiliste leidude (nt loitsutahvlid, amuletid) põhjal (nt Faraone \& Obbink 1991; Luck 2006; Ogden 2002; Boschung \& Bremmer 2015).

Arheoloogiliste leidude tõlgendus on keerukam, sest nende kohta puuduvad narratiivid ja nendest tulenevad valmis interpretatsioonid. Maagilisi tõlgendusi on välja pakutud üliharva, sest lihtsam ja turvalisem on kasutada vähem spekulatiivseid lähenemisi. Oma osa on sellele lisanud kindlasti ka teoreetilises arheoloogias aastakümneid käibinud seisukohad, mille järgi arheoloogia ei olegi võimeline uurima religiooni ja maagiat (Hawkes 1954), ning seega on selliseid uurimusi pigem kritiseeritud. Ka 2011. aastal ilmunud käsiraamatus "Oxford Handbook of the Archaeology of Ritual and Religion" (Insoll 2011), puudub eraldi maagia peatükk ning maagiat on mainitud vaid historiograafilistes ülevaadetes.

Maagiliste tõlgenduste pelgamine nii etnograafias kui ka arheoloogias on viinud omalaadse suletud ringini, kus selliseid esemeid ei nähta, ei tunta ära ega koguta, sest neid ei osata adekvaatselt tõlgendada ega peeta oluliseks. Sellest ringist väljasaamiseks olekski tarvis tuua maagia kui tõlgendusvõimalus akadeemilisse diskussiooni. Heaks näiteks on ehitusohvrite teema Soomes, mida enne esimesi ilmunud uurimusi (Hukantaival 2007; 2009) ei osatud tähelegi panna. Seega, maagiliste esemete kui uurimisteema toomine akadeemilisse diskussiooni on üks võimalus laiendada selliste objektide ringi. Käesolevas artiklis tutvustame Eesti muuseumikogudes säilitatavaid esemeid, mida on teadaolevalt kasutatud maagilisel viisil ning arutleme filosoofiliste ja ideoloogiliste põhjuste üle, miks on esemeid maagiaalastes käsitlustes nii vähe puudutatud.

\section{Maagia ja esemed Eestis}

Eestis alustati maagiaga seonduva kogumist ja uurimist juba 19. sajandi keskel (nt Kreutzwald \& Neus 1854), süstemaatilisemalt alates sajandi lõpust koos rahvaluule kogumisega, kus eraldi on ära mainitud ka ebausklikud kombed (Hurt 1888). 20. sajandi esimesel poolel käsitlesid mitmed Eesti Rahva Muuseumi (ERM) küsitluskavad erinevaid rahvauskumuste küsimusi ning 19. sajandi vaimus koguti "kohe hävivat kombestikku" (tähtpäevad, ravivõtted 
jms). Kogumistöö pidi olema täielik, seega koguti rahvausundi kõigi aspektide kohta käivaid lugusid. Laiahaardelisest tekstikorpusest on mitmed teemad praeguseks võrdlemisi hästi läbi uuritud, nt loitsud (nt Kõiva 2011), rahvaarstid (Kõiva 2013, 2015; Kõivupuu 2013, 2014), rahvameditsiin (Tupits 2009), taimravi (Kalle \& Sõukand 2010), kaitsemaagia (Reet Hiiemäe 2012).

Kuigi maagiliste esemete vastu on alati rohkem või vähem huvi tuntud, on materia magica alles viimasel aastakümnel omanäoliseks uurimisteemaks kujunenud, seda küll peamiselt mujal maailmas, üksikuurimuste puhul ka Eestis (nt Valk 2004; Jonuks jt 2010). Lähtuvalt kõige üldisemast arusaamast maagia kohta (vt definitsioone nt Flint 1991: 3; Morris 2006: 234) peaks maagilisi objekte käsitlema kui esemeid, millele omistatakse üleloomulikku väge ja/või mida kasutatakse üleloomulikku väge eeldavates tegevustes tööriistana. Nii on maagilisena võimalik tajuda ka neid esemeid, mis pealtnäha kuidagi tähelepanuväärsed ei ole. Klassikaliste kaitsemaagia näidetena Eesti arheoloogias on tihti viidatud kiviaegsetele figuuridele (Jaanits 1961: 58; Jaanits et al. 1982: 98) - tees, mis sobib hästi teadusliku ateismiga, mille järgi kasutasid primitiivsed inimesed maagiat, et toime tulla looduse ähvardavate jõududega. Pronksi-, raua- ja keskaja kontekstis on traditsiooniliselt keskendutud ripatsitele ja (kaitse)maagiat on omistatud ennekõike hammasripatsitele kui kõige sobivamatele (Vassar 1943: 81; Selirand 1974: 154). Vaadates maagia mõistet märksa laiemalt saab määravaks hoopis leiukontekst. Loomakolju keskaegse linna kontekstis on iseenesest täiesti tavaline arheoloogiline leid, eluhoone nurga alla paigutatult võib aga omandada täiesti teistsuguse tähenduse - talisman, mis pidi kaitsma maja ja selle asukaid (Hukantaival 2009). Samamoodi võib kivikirvest pidada kiviaegseks tööriistaks, aga kui see on paigutatud trepi alla või müüritud ahjuseinakivide hulka, on ta maja tule eest kaitsev maagiline objekt (Johanson 2009). Igapäevamaagia kontekstis võib suvalisest esemest saada üleloomulikku väge vahendav maagiline vahend, nt sõel ja käärid ennustamisel (Valk 2004), kirves ja raudnael (Hiiemäe 2012: 72) või toiduained (nt sool) tõrjemaagias (samas: 87 jj). Esmapilgul paradoksaalselt võivad igapäevarituaalides maagilise rolli omandada ka ametliku religiooni toimesse kuuluvad esemed (nt Piibel, armulaualeib jne) (Johanson \& Jonuks 2015). Seega on kogu elu nii tihedalt seotud üleloomulike jõudude mõjutamise vajadusega, et maagilistes praktikates kasutatud esemeid peaks olema olnud oluliselt rohkem, kui leidub meie muuseumikogudes. 


\section{Maagilised esemed Eesti muuseumikogudes}

Esimesed maagiliseks peetud esemed jõudsid Eesti muuseumikogudesse 19. sajandi keskel, mil baltisaksa päritolu Vene laevastikus teenivad kaptenid, kes viisid läbi nii ümbermaailmareise kui tegelesid aktiivselt Arktika uurimisega, tõid oma rännakutelt kaasa esemeid. Selle käigus on jõudnud ennekõike Eesti Ajaloomuuseumisse (endine Provintsiaalmuuseum) eksootilisi esemeid, millest mitmed on ka klassikalised maagilised objektid, nagu näiteks vaimolendite figuurid (Rousselot \& Grahammer 2004; Jonuks \& Saage 2015). Samal ajal kujunesid baltisaksa valgustus- ja romantismiajastu ajaloo huvilisi intellektuaale koondavad ja kodumaa ajaloost huvitatud õpetatud seltsid, mis pidasid oma eesmärgiks muinasesemete kogumist ning teostasid seda arheoloogiliste kaevamiste abil. Nii hakkasid kiirelt kasvama peamiselt arheoloogilised ja numismaatilised kogud (Tvauri 2006: 225-227).

Kuigi 19. sajandil ilmusid esimesed Eesti rahvausu fenomenide käsitlused (nt Knüppfer 1836), pandi alus Eesti mütoloogiale ja ilmus ka esimene ülevaade maagilistest lauludest (Kreutzwald \& Neus 1854), ignoreeris enamik religioonikäsitlustest selle ainelist poolt. Seetõttu ei pööratud maagiliste esemete kogumisele tähelepanu ka muuseumites, ja selline traditsioon on üldjoontes jäänud püsima tänini. Nii saabki Eestis välja tuua peamiselt kahe muuseumi kogud, kuhu on jõudnud maagilise taustaga objekte - Pärnu muuseumi (PäMu) harrastuskollektsionääride kogud ning Eesti Rahva Muuseumi (ERM) rahvameditsiini kogu.

Pärnu Muuseum tegeles Pärnu Muinasuurimise Seltsi tegutsemisaegadel (1896-1940) peamiselt arheoloogiakogude täiendamisega. Etnograafilise materjali (igapäevase tarbevara) lisandumine oli juhuslik ning seotud üldise vajadusega koguda vanu tööriistu ja rahvariideid. Kõige enam pärimusliku kasutusega seotud esemeid on arst Martin Bolzi kogus (kogutud 1890-1913). Bolzi kogu kujunemisele aitas kaasa ka tema arstipraksis, sest külades palju ringi liikudes sai ta uurida talurahvalt nii varasemalt kui kaasajal hinnatud piksenoolte kohta ja neid omanikelt suurema või väiksema vaeva ja veenmisjõuga endale küsida või osta (Bolz 1914: I). Piksenoole pärimust on üles kirjutanud teisedki Pärnu kandi kollektsionäärid: "talumehed, kes vee ääres elavad, peavad kirveid piksenoolteks, panevad neid heinaküüni, et kaitseks välgu eest, veel praegu vaadeldakse neid kui maavälist päritolu mineraale, "pikse talwet", millel peaks olema ravitoime, kasutatakse masseerimisel kooljaluude vastu ja nahapõletiku roosi vastu. Noorem põlvkond hävitab neid, sest kontrollivad nende kulla- ja teemandisisaldust, mis oletatavalt peaks neis olema ja siis lõhuvad" (Glück 1906: 311-312). Bolzi kogu 1914. aasta publitseeritud kataloogis on 500 eseme 
hulgas 20 kivitalba või -kirvest, mille kohta on kogutud kas piksenoolepärimus või kirjeldatud kiviesemega ravimist. Veel 15 sellist on kirjeldatud praeguseks kadunud või kogumata (ei antud ära) jäänud 107 eseme hulgas (Bolz 1914). Huvitaval kombel on muuseumikogusse jõudnud vaid kaks eset, mida on kasutatud (roosi) ravimiseks, samas kui kogumata jäänud 15 pärimusega seotud eseme hulgas on ravi- või kaitsemaagiat kirjeldatud üheksal juhul. Piksenooli pandi laste vannivette, kui lapsed olid haiged, kasutati erinevate haiguste korral, hoiti kaitse eesmärgil loomade joogivees jne. Ilmselt väärtustati ja kasutati ravimaagias kiviesemeid eelmisel sajandivahetusel veel niivõrd, et neid ei müüdud ka kalli raha eest, mille maksmise poolest Martin Bolz eriti kuulus oli (vt nt Pulst 2006: 37).

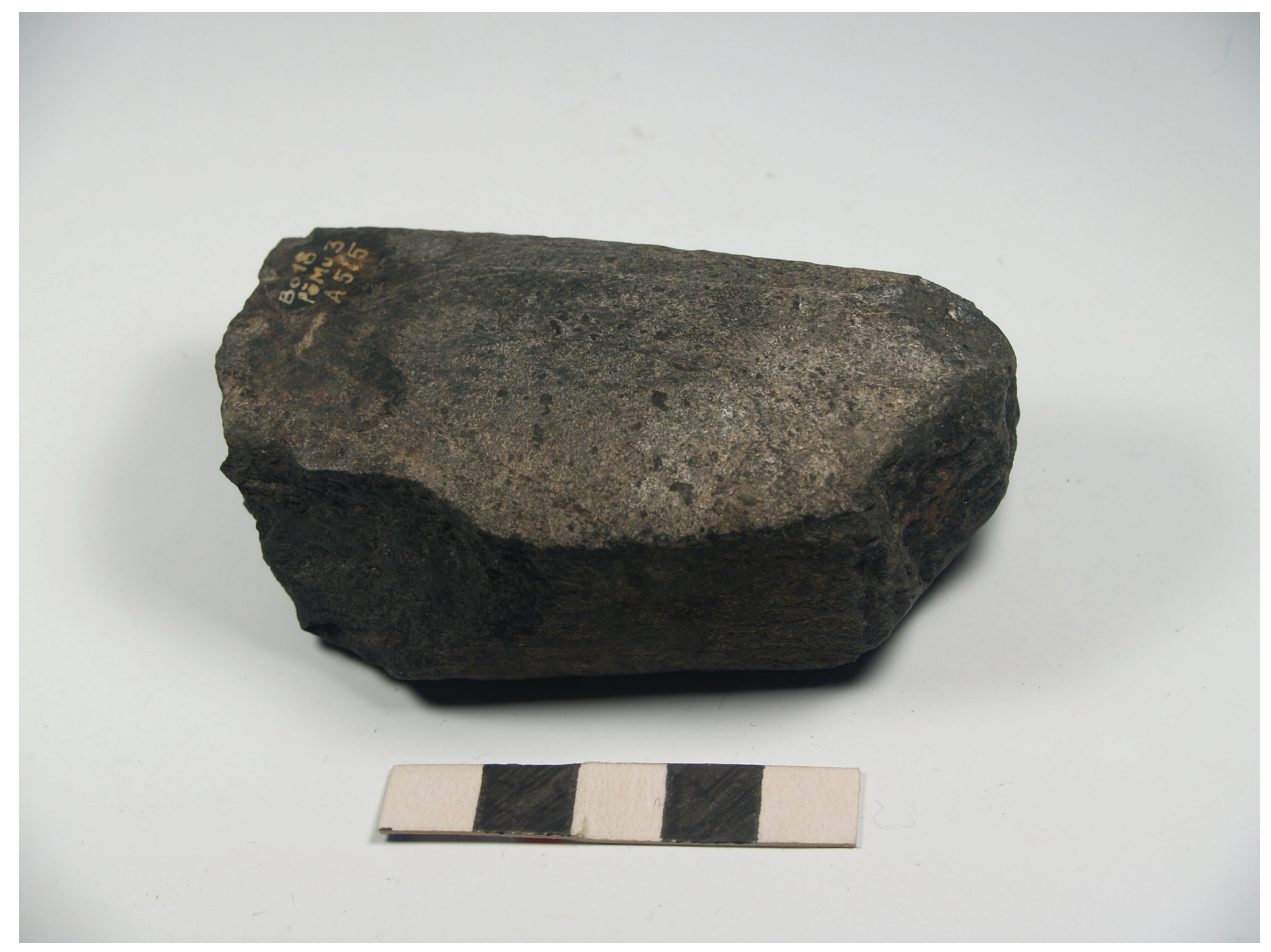

Joonis 1. "Leitud Uue-Vändra ms, Vihtra-Ülejõe talu maalt Pärnu jõe vasakul kaldal, pikselöögist tabatud kuuse juure alt Karl Kuuse poolt 1836. Talb oli algselt terve lametalb, kuid löödi katki, et teistele meestele ka imettegeva jõuga "piksenoole" tükke anda. Ostetud leidja pojalt Kaarel Kuuselt 17. jaan 1896” (PäMu 3/A515). 


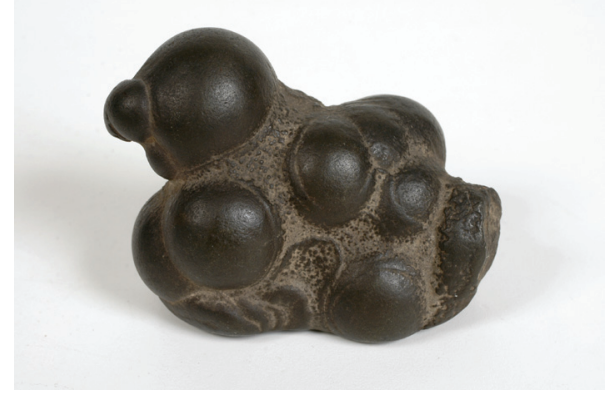

1

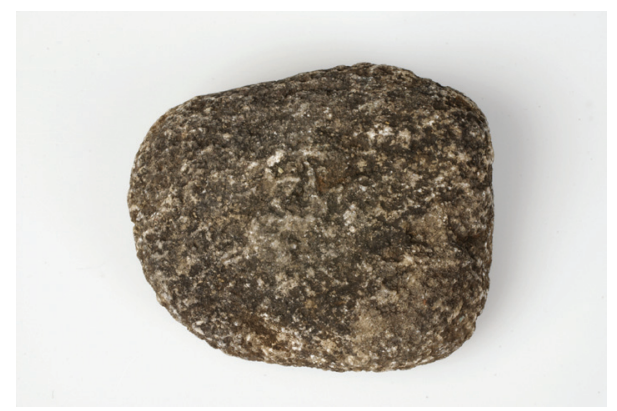

$3 a$

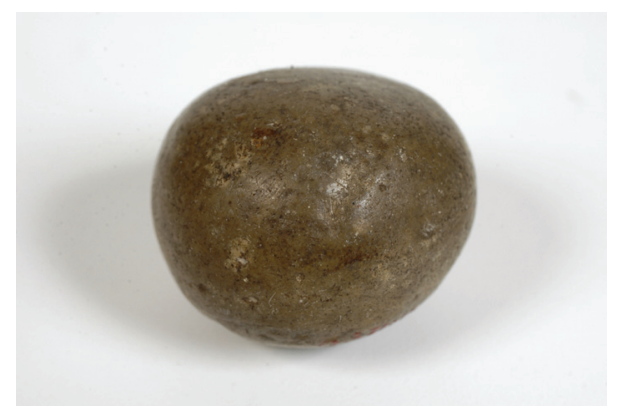

4

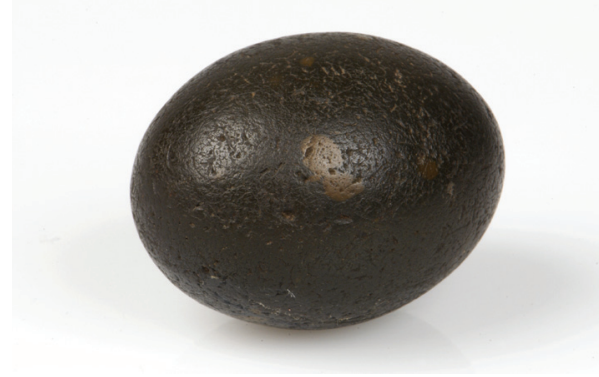

2

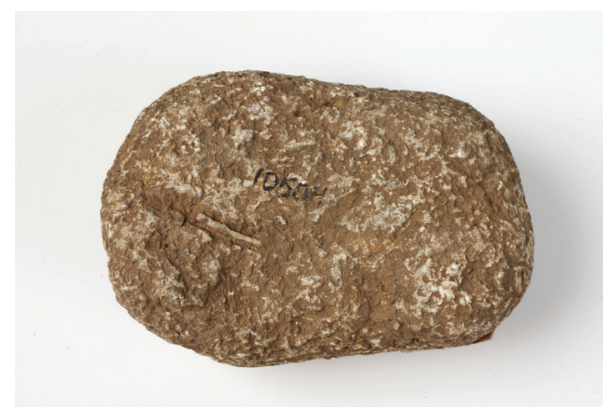

$3 b$

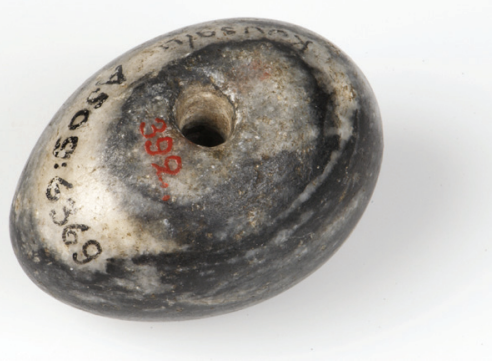

5

Joonis 2. 1. "Piksekivi.Kiviga olla haigeid terveks tehtud, meteori kivi" (ERM 6944). 2. "Must, ümmargune, munataoline kivi, millest rahvas räägib, et kaaren suure reede või suure neljapäeva hommikul oma lapsi sellega ristivat. Kaaren olevat kivi kusagilt mere äärest oma pesasse toonud. Kivi nr 7797 olevat kindlasti kaarna pesast leitud. Vanasti arstitud temaga paistetuse haigusi: haigele kohale vajutatud kiviga pääle, siis saanud ta terveks. Kinkija on kivi oma vanaisa käest saanud, kes ta omalt isalt pärandanud. Vanadus igatahes väga kõrge" (ERM 7797). 3. "Nõiakivi. Kivi on tarvitatud nõidumiseks, kinkija teab, et tema vanaema on selle kiviga veel nõidunud. Vanus kinkija ütluse järele 200 a.” (ERM 371: 14); 4. "Rahkkivid. Kui lastel kivi-maaalused [vistrikud] olid, otsiti metsast 9 rahkkivi, aeti ahjus tuliseks, visati sooja vette ja lasti auru lastele peale, siis kadusid maaalused" (ERM 10504). 5. "Kivi tarvitatud Kuusalu khk, Kolga v, Uuri külas. Saadud samast Iisaka t Anna Albreltaali käest 1920. a. Saadud mehe isa-isa-isalt. Umbes 125 a vana. Sajajalgsete tegemiseks Jaani laupäeva öösel, omanik ja tarvitaja seesama. Kuidas aga tarvitati, on ära unustatud." (ERM 509: 6369). 
Eesti Rahva Muuseumi kogu on maagilisena kasutatud esemete poolest Eestis kõige rikkalikum. Enamasti on tegemist ravimaagiliste esemetega, mis on kataloogitud rahvameditsiini kogusse koos teiste ravivahenditega (nt rohupudelid, kõrvalusikad, pintsetid jne). Mõningad ravis kasutatud esemed on aga kataloogitud hoopis nende utilitaarse funktsiooni järgi. Näiteks ehtekollektsioonis leidub kuus sõlge, mille küljest kraabitud hõbevalget on legendi kohaselt kasutatud ravimiseks, veel 40 sõlel on servas sarnased vigastused, ehkki vastav legend puudub (Kuningas 2014: 6). Vaid kahe erandiga on rahvameditsiini kogu maagilistes toimingutes kasutatud esemete puhul tegemist ajavahemikus 1909-1940 kogutud asjadega, mis on muuseumi jõudnud peamiselt üleriigiliste kogumisretkede tulemusel.

Rahvameditsiini kogu maagiliste arstimisvahendite hulgas leidub väga eripäraseid esemeid. Valdav osa neist on eriilmelised kivid, mida on erinevalt nimetatud: nt piksekivid, piksekuulid ja piksenooled, kaarnakivi, narritsa ${ }^{1}$ kivi, nabakivi, arstimise kivid, kivisüda, kivipulk, nõiakivid, rabandusvastane kivi. Piksekivide hulka koguti ka mõned piksenoole pärimusega kivikirved, mis deponeeriti aga funktsionaalse museoloogia raames arheoloogia kabinetti (praegu Tallinna Ülikooli arheoloogia (AI) teaduskogu), kuna funktsioonilt on tegemist kiviaegsete tööriistadega. ERMi jäänud piksekivid on aga ümarad või ovaalsed, võrdlemisi pisikesed siledad kivid, lihvunud paekivimunakad, vahel ka püriidimugulad. Piksekivide kirjeldustest on teada, et nendeks on peetud kas ühest otsast ümaraid, teisest teravaid (kivikirved, talvad), aga ka ümaraid kanamunasuurusi siledaid kive. Seega sobivad ERMis säilitatud ja säilitatavad esemed hästi ka folklooriteadete kirjeldustega. Vahel on piksenoolteks nimetatud ümaraid tavalisest kivist raskemaid püriidimugulaid, mida on seostatud "meteoriitidega" - siin on selgelt kokku pandud kooliõpiku teadmine taevast langevatest meteoriitidest ning folkloorne teadmine müütilistest piksenooltest ning need omistatud ebahariliku kujuga kividele. Kivisüdameks ja kivipulgaks on nimetatud peajalgsete kivistunud noolja kujuga sisekodasid, mida Eesti paekivides leidub arvukalt. Folkloorikogudes on säilinud hulgaliselt kirjeldusi piksenoolte/-kuulide/-kivide ja peajalgsete fossiilidega ravimisviiside kohta. Kõige levinumad on jutud, kus räägitakse piksenoolega kasvajate või paisete vajutamisest, samuti on piksenoole küljest puru kraabitud, mida hambavalu või rabanduse korral kasutada, piksenoolt on hoitud loomade joogivees, et need kängu ei jääks jne (vt lähemalt piksenoole saamise ja sellega seotud kaitse- ja ravimaagia kohta Johanson 2009; Hiiemäe 2012: 96).

Eripärasemad esemed ravikivide hulgas on kaarnakivi ja nabakivi. Kaarnakivi (Joonis 2:2) legend on üleeuroopalise päritoluga - uskumuse järgi võis neid leida kaarna pesast, kusjuures kaaren olevat toonud selle Ees-Aasiast Jordani jõelt vm kaugelt soojalt maalt (Eisen 1926: 311-313). Kataloogitud kivi (ERM 7797) on must ja sile munakujuline ümar kivi, mis olla väga vana ja isalt pojale 
põlvest põlve pärandatud, sarnaselt piksenoolele olevat sellega ravitud paistetusi. Nabakivi (ERM 7403), mille auku pandi põlev paber ja kaeti see klaasnõuga, on kasutatud omalaadse abivahendina kupupanemise laadses raviviisis. Seega võib seda pidada pigem lähedaseks kõrvakividega, mille puhul on olulisem konkreetse kivi kujust tulenev sobivus rituaali jaoks ja kivi oli osa ratsionaalsest raviviisist. Kui enamik ravikive on ilusad, ümarad ja siledad, lihvitud või looduslikult lihvunud, siis teistsuguse näitena võib tuua kaks tavalist nurgelist paekivitükki (ERM 10504, joonis 2:3), mille kunagine omanik tõi välja siis, kui koguja küsis nõiakivide järele. Informandi sõnul on kivid osa metsast korjatud üheksast kivist, mis tuli ahjus tuliseks ajada ja sooja vette visata, et tõusev aur parandaks lastel maa-aluste haigust. Ka rahvapärimuses on teateid kividest, mis ei peagi kuidagi efektsed välja nägema. Mõnel eesmärgil on sobinud meie mõistes juhuslik, nt nelja tee ristist või sauna eest korjatud kivi, mille soetamise asjaolud (aeg ja koht) annavad kivile tema maagilise väe.

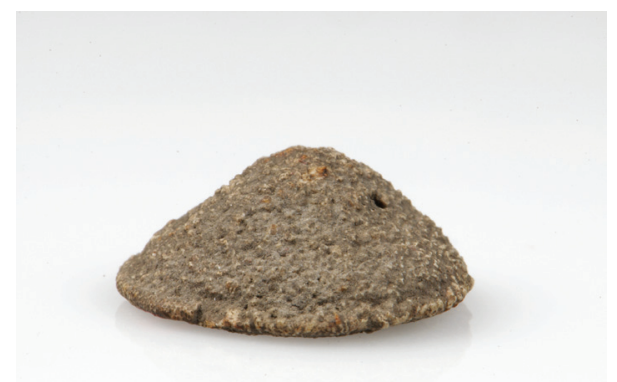

1

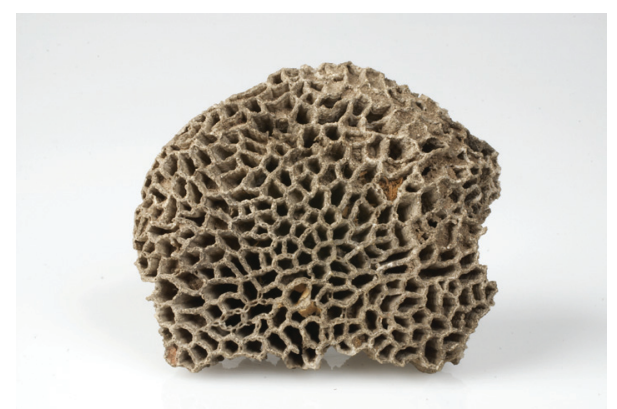

3

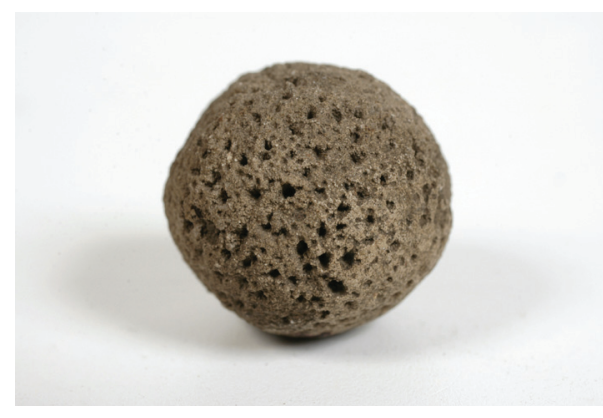

2

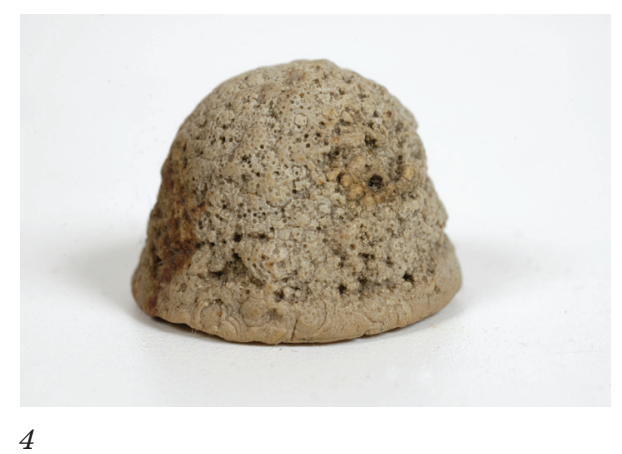

Joonis 3. Kõrvakivid. 1. "Palavaks aetud kivi lasti külma vee sisse ja kõrv sellest tõusva auru kohale. Parandas alati kõrva valu" (ERM 17067). 2. "Kivi tarvitati vanasti kõrvahaiguste arstimiseks: kivi aeti kuumaks, vett valati pääle ja auru lasti haigesse kõrva. Kivi, mille aur mõjunud, pidanud tingimata väikesi augukesi täis olema. I nagu kõrval auk on, peab ka kivil olema, millega arstitakse" (ERM 7798). 3. (ERM A310: 46). 4. "Ühtlasi saadan teile niinimetatud kõrvakivi, millega veel mõnikümmend aastat tagasi on arstitud kõrva haigused sel teel, et kivi aeti tules kuumaks ja valati tema peale vett, millest tekkinud aur juhiti kõrva” (ERM A 502: 124). 
Lisaks nõia-ja piksekividele on ERMi kogus kümmekond kõrvakivi (Joonis 3) need on väikesed, koonilised ja ümara otsaga fossiilsed sammalloomad või poorsed korallid (ahelkorall, päikesekorall). Ka pärimus nende kohta on väga ühetaoline - kõrvavalu korral aeti kivid kuumaks ja kallati neile peale kuuma vett ning seejärel juhiti soojendav aur kõrva või pandi kivi ise kõrva, kuniks kõrvavalu järele andis. Nähtavasti toimis selline soojendusviis külmetusest tingitud kõrvapõletiku puhul leevendavalt ning seega oli tegemist selgelt funktsionaalse ravivõttega. Ka ei ole kõrvakividega ravimisel olnud vaja lugeda nõiasõnu, mis samuti viitab ravivõtte funktsionaalsele iseloomule.

Üksikesemetena on raviesemete kogus arvukalt näiteid. Näiteks säilitatakse kogus ravimiseks kasutatud rahvariidevöö otsa (ERM 282), kusjuures ülejäänud vöö olevat omanik jätnud endale kasutamiseks. Raviks kasutatud vöid on kataloogitud ka rahvarõivaste all (Õunapuu 2015: 167). Rahvariidevööga roosi ja ussihammustuse ravimine oli levinud komme, samuti kasutati vööd kaitsva esemena maagilises piiramisrituaalis (Hiiemäe 2012: 76 jj). Kogus on ka üks arstimiseraha (ERM 14356) - 18. sajandist pärit vene kopikas, millega raviti
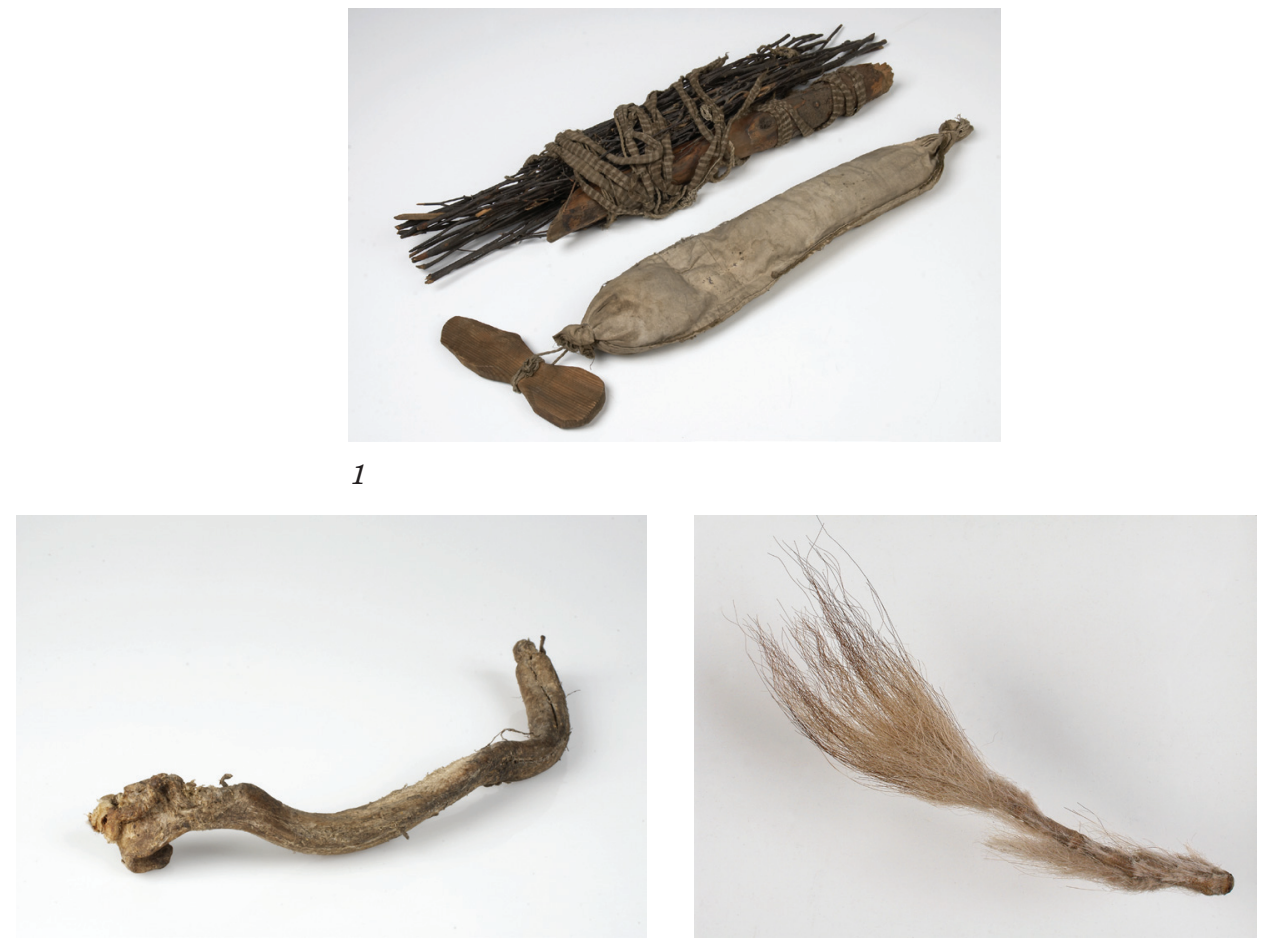

3

Joonis 4. 1. Kratt (ERM A 291: 503). 2. "Härjakara. Tarvitatakse arstirohuks elajatele. Kui kusi kinni on, tükeldatakse kara ja antakse joogi sees elajatele sisse” (ERM A 282: 110). 3. "Hundi saba, nõidumisabinõu; tarvitati saunas tüdrukute vihtlemiseks, kes ruttu mehele tahtsid saada” (ERM A 35: 1). 
inimestel ja loomadel luumurde - raha küljest tuli vaske kraapida ja joogivette segada. Väidetavalt sobisid paremini suuremad ja vanemad rahad, sest nende vaske peeti puhtamaks. Münt ongi selgelt lopergune, mis viitab servade viilimisele. Üksiknäitena on kogus ka hundisaba (ERM A 35:1, joonis 4:3), mida olevat kasutatud tüdrukute vihtlemiseks, et aidata neid kiiresti mehele saada. Sümpateetilist maagiat esindavad kuivatatud härjapeenis (ERM A 282: 110, joonis 4:2), mille tükke oli loomadele urineerimisprobleemi puhul sisse joodetud, ja hülge kõri (ERM A 492: 14), mille kaudu joodi, kui kael haige.

Selgelt maagilise taustaga on Tartu lähedalt põllult leitud ja teadaolevalt ainsana materiaalsel kujul säilinud kratt (ERM 291: 503, joonis 4:1). Rahvapärimuses laialt tuntud motiivina on tegemist inimese meisterdatud olendiga. Hinge kuradile müües sai elustada olendi, kes seejärel hakkas peremehele kandma kokku vara, kuni ta peremehe surma ajal viis tolle hinge põrgusse. Kratt on tavaliselt tehtud lihtsatest ja käepärastest vahenditest, nagu seegi oksapuntrast ja riideräbalatest valmistatud osaliselt säilinud nukk. Teistest kujudest on kogudes esindatud viljakushaldjas Peko (ERM A387: 64) ja koduhaldjas Tõnn (ERM A563: 782).

\section{Kogujate ja museoloogide omistatud maagilisus}

Lisaks selge narratiivse taustaga esemetele on mitmed esemed kataloogitud maagiliseks ka ilma otsese viiteta sellisele kasutusele. Üheks näiteks on piksekivi (piksetalv, ERM 6748), ümar hallikas sile lubjakivimunakas, mis olla leitud maa seest. Korjamisraamatus seisab: "Kuulujut: Wanal ajal olla kasujaid ja m. triigitud" (Korj rmt 83:103: 1912). On tõenäoline, et kinkija oli kivi korjanud maa seest, sest oma siledusega torkas see silma, ent reaalselt seda ei kasutatud ning kogujale esitati versioon ümmarguste kividega ravimisest.

Ootamatult leiab arstimisvahendite hulgast ka priapuseks nimetatud kivi (ERM 13368, joonis 5:1). Kivi leidis 1912. aastal mererannast ilmselt koguja ise, kes võrdleb kivi sigivusmaagiliste pulmarituaalidega seotud atribuutide, nn pulmamunnidega. Üksikuid teateid peenist meenutavate esemete kasutamisest Eesti pulmarituaalides on (vt Kruusberg 1920: 45), ning üksikjuhtudel on peenise kujutist kantud ka uusaegsetele (pulma)ehetele. Tegemist on küll tõenäoliselt loodusliku huvitava kujuga kiviga, kuid kuna koguja omistas sellele rituaalse tähenduse, siis on juba Aleksander Kruusbergist alates (1920: 46) arvatud, et see võib olla inimkäte tehtud. Sarnaseid kahtlusi tekitab ka koduhaldjas Tõnn, mille kohta koguja on märkinud, et "võib olla tegemist ajajooksul unustusse jäänud esemega, mida hiljem suitsununa on hakatud pidama tondiks või tõnniks, nimelt võib, et mingile okslikule puule on pähe tõmmatud oinakott, karvad sisse poole. Nii kuivatati oinakotte" (ERM pearaamat). Ometi on seda korduvalt ja kahtlusteta haldjanukuna presenteeritud (nt Õunapuu 2015: 54 jj). 
"Ehk nõiduseks tarvitatud” - maagilised esemed Eesti muuseumikogudes
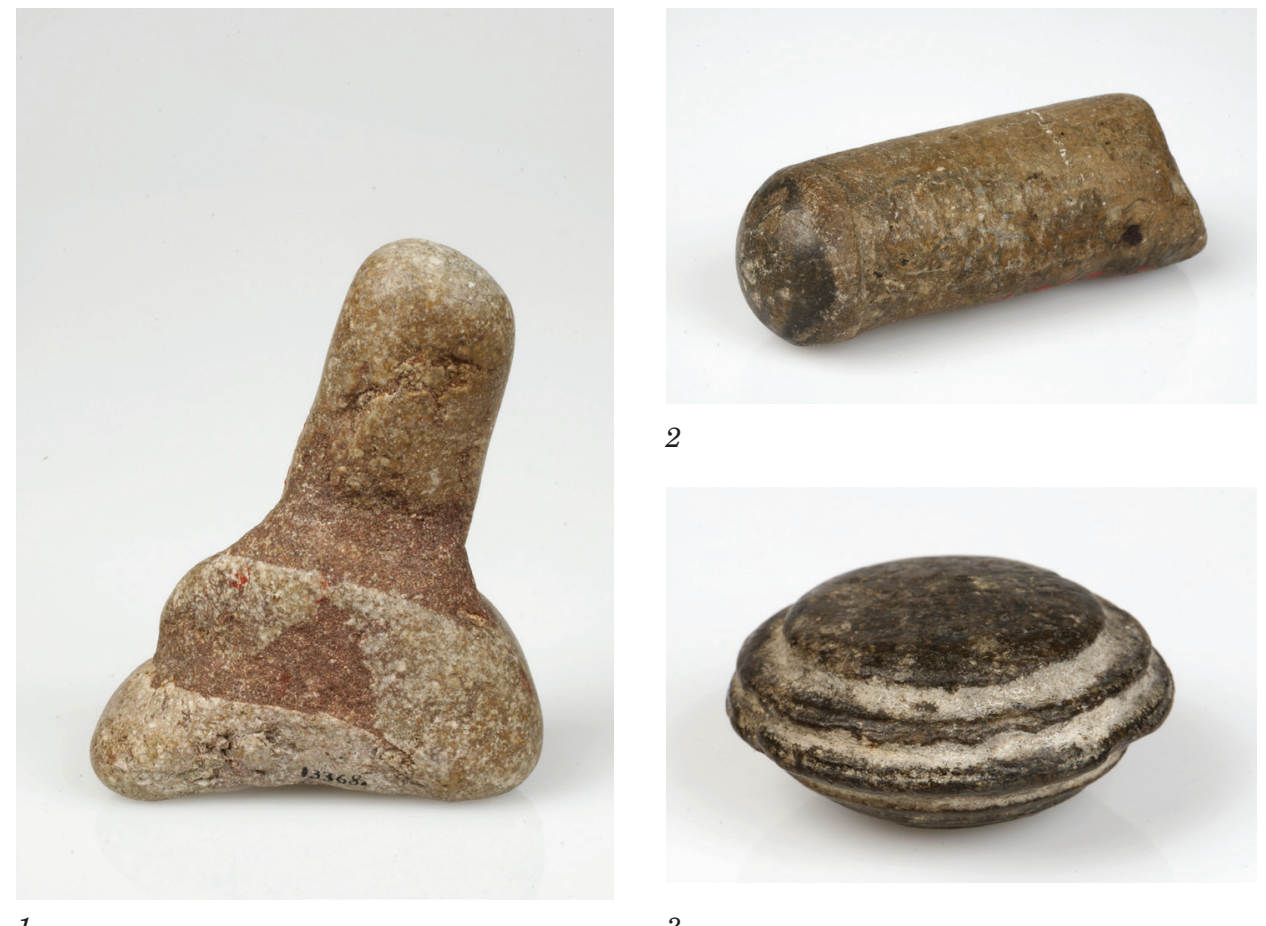

2

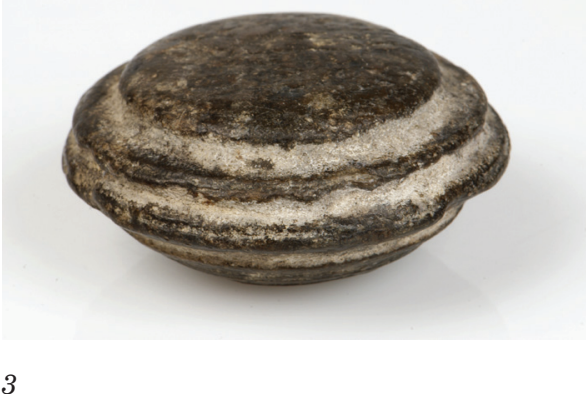

Joonis 5. 1. "Leitud Jõhvi lähedal mere rannal liiva seest (Voka rannast). Kas juhuslik kivistus ehk priapus [efr. Viedemann, Aus d. Inneren u äusseren Leben p 318, 322]. V. Grünthal on Saaremaal sarnast asja näinud. Karvadeks olnud sell tükk lambanahka villadega [pulma "munn”]. Ehk ka kivistusest välja tehtud.” (ERM 13368); 2. "Kivipulk, ühest otsast pisut ahenev, konkaav otsaga, jämedam ots murdunud. Pikkus $8 \mathrm{~cm}$, ümbermõõt kuni $10 \mathrm{~cm}$. Leitud aidast tohuvakast koos meteooriga. Nähtavasti arstimisvahend." (ERM A 353: 3). 3. "Piksekivi. Kinkija mehe isa isa leidnud Käsmu rannast "Naari"” taoline. 2 tolli läbimõõduline vee ümarguseks uhutud kivi. Ehk nõiduseks tarvitatud.” (ERM 16152).

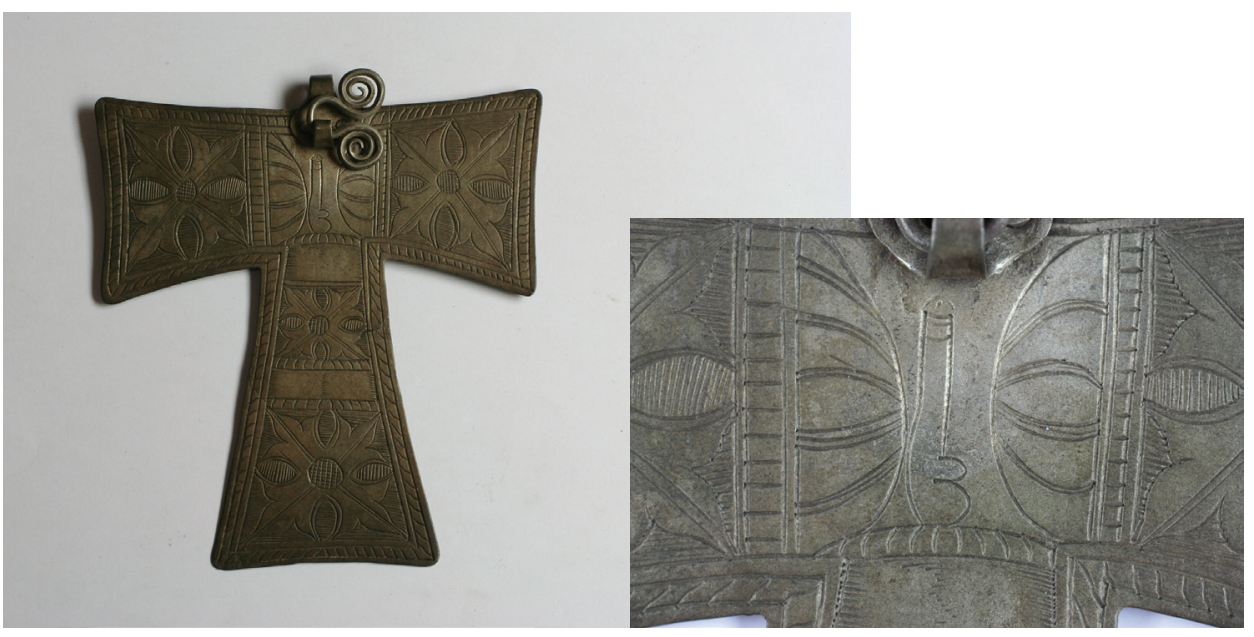

Joonis 6. Üks väheseid teadaolevaid ripatseid fallose kujutisega (ÕES 1202: 1). 
Eriti huvitavad ongi kogus esemed, mida reaalselt maagilistel eesmärkidel kasutatud ei ole. Tegemist on potentsiaalsete nõiaesemetega, ravivahenditega, seega oli nende hankimine muuseumile toonaste kogujate seisukohalt suuresti samaväärne päriselt kasutatud esemete korjamisega. Toonased kogujadki olid eri taustaga, paljud pärit küladest ja kasutanud rahvaravivõtteid kogu oma lapsepõlve, nende silmis ei olnud "maagilistes" võtetes midagi maagilist. Näiteks ERMi korrespondent ja hilisem kunstnik August Pulst ravis oma korjamisretke ajal saadud ussihammustust naabrinaise ussisõnade ja havihammastega (Pulst 2006: 106-110). Just Pulsti korjamisraamatus esineb sagedasti erineva kujuga kivistisi, mida ta ise jõe kaldalt liiva seest korjas ja muuseumi tõi. Enamikku neist siiski muuseumis arvele ei võetud. Samas olid esindatud ka "teadusliku" maailmapildiga kogujad, kes suhtusid sellistesse ravivõtete toimesse kahtlustega või lausa taunivalt, mida illustreerib järgnev tsitaat: "Rahva ebausku näitab paar juhtumist kus räägiti et poeg olla käe või jala ära nikastanud ja selle rohuks sõle ehk preesi ära söönud. Niisama tarvitatas hõbe rublasi mille rist pääl on roosi haiguse vastu rohuks" (Heiber jt 2012: 40-41).

Ilmselt on just (ala)teadlik analoogia rahvameditsiinist tuntud ümarate kivide ja fossiilide-kristallidega põhjuseks, miks ka arheoloogiakogudesse on selliseid objekte korjatud. Võimalikule analoogiale rahvapäraste ravimaagiliste kivide ja arheoloogilise materjali vahel on tähelepanu juhtinud näiteks Heiki Valk oma informandi Anne Linnupuu vanaemast rääkides: “... see kes teadis ravimisekunsti ja ümarovaalsete, tuvimuna taoliste siledate kivikestega haigusi ravis. Niisuguseid kivikesi tuleb asulakohtadest ikka välja ja tuli ka Uusvada kaevamiste ajal" (Valk 2005: 3, joonis 7). Lapikuid või ümaraid siledaid kive ning fossiile on üles korjatud erinevate perioodide asulatest ja matusepaikadest kokku üle poole tuhande, ent peaaegu eranditult on nad jäänud käsikirjalistesse leiunimekirjadesse ning publitseeritud tõlgendusi nende kohta on pakutud vaid harvadel juhtudel. On üpris ilmne, et kuna maagiline seletus ei tundu piisavalt teaduslik ega tõestatav, on uurijatel olnud lihtsam ja turvalisem eirata edasises uurimistöös nii esemeid kui ka sellist spekulatiivset tõlgendust. Üksikud tõlgendused, mis kividele antud, peegeldavad selgelt rahvapärimustekstidest pärinevat teavet, mida on arheoloogilise materjali puhul kasutanud vaid üksikud “julged" uurijad. Üheks selliseks on Richard Indreko (1939), kes on 1930. aastail Asva kindlustatud asulast kogutud ümaraid kive interpreteerinud kärnkonnakividena. Vello Lõugas on oma käsitluses ettevaatlikult omistanud piksekivi tõlgendust kivikalmetest kogutud arvukatele ümmargustele kividele (Lõugas 1996: 117). Lisaks on käsikirjalistes leiunimekirjades ümaraid kive nimetatud näiteks soonetasumise kivideks (I Kuusalu asulakoht...), ussikivideks (Kustin 1963a, 1963b), maagilisteks ravi- või nõidumiskivideks (Jaanits 1953: 330) või ravikivideks (Haak 2001), enamasti aga siiski lakooniliselt vaid "kivideks". 


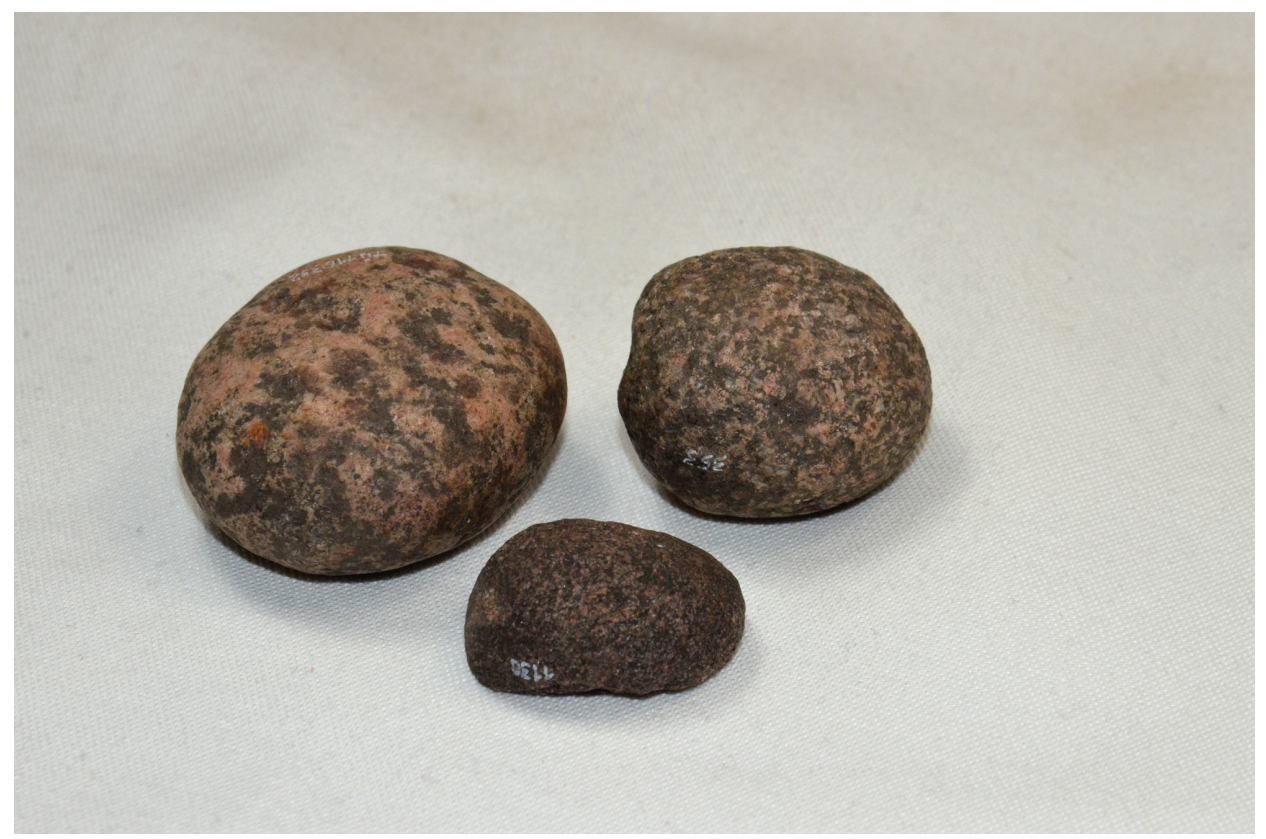

Joonis 7. “...see kes teadis ravimisekunsti ja ümarovaalsete, tuvimuna taoliste siledate kivikestega haigusi ravis. Niisuguseid kivikesi tuleb asulakohtadest ikka välja ja tuli ka Uusvada kaevamiste ajal” (TÜ 116: 352, 353, 1130).

\section{Maagia näitustel}

Esimesed muuseuminäitused Eestis avati peagi pärast muuseumite loomist 19. sajandi esimesel poolel ja neil eksponeeriti eripäraseid kuriositeete ja kogutud "vanu asju". Neist erinevam oli 1923. aastal avatud ERMi püsiekspositsioon, mille eesmärk oli kujundada rahva kultuurimälu - näidata, mis on Eesti traditsiooniline rahvakultuur ja millised nähtused-esemed on sellele iseloomulikud (Nõmmela 2010). Noor Eesti riik ja rahvas, kes ei saanud oma ajaloost esile tuua etnilise valitseva kõrgkihi olemasolu, pidi toetuma talupoeglikule päritolule ja muutma selle oma tulevase kõrgkultuuri aluseks ning rahvakultuuri sisuks (Nõmmela 2009: 117). Põhirõhk oligi toonasel näitusel seega rahvarõivastel ja tarbeesemetel (nt õllekannud, tööriistad jne), vaimsele maailmale viitas vaid üks eksponaat - setude pühasekast (Rahvasteaduslikkude kogude juht 1923). Eksponeeriti kogutud materjali, mis pidi olema korraldatud teaduslikult, ülevaatlikult ja jätma esteetiliselt kauni mulje, teaduslikkus pidi garanteerima 


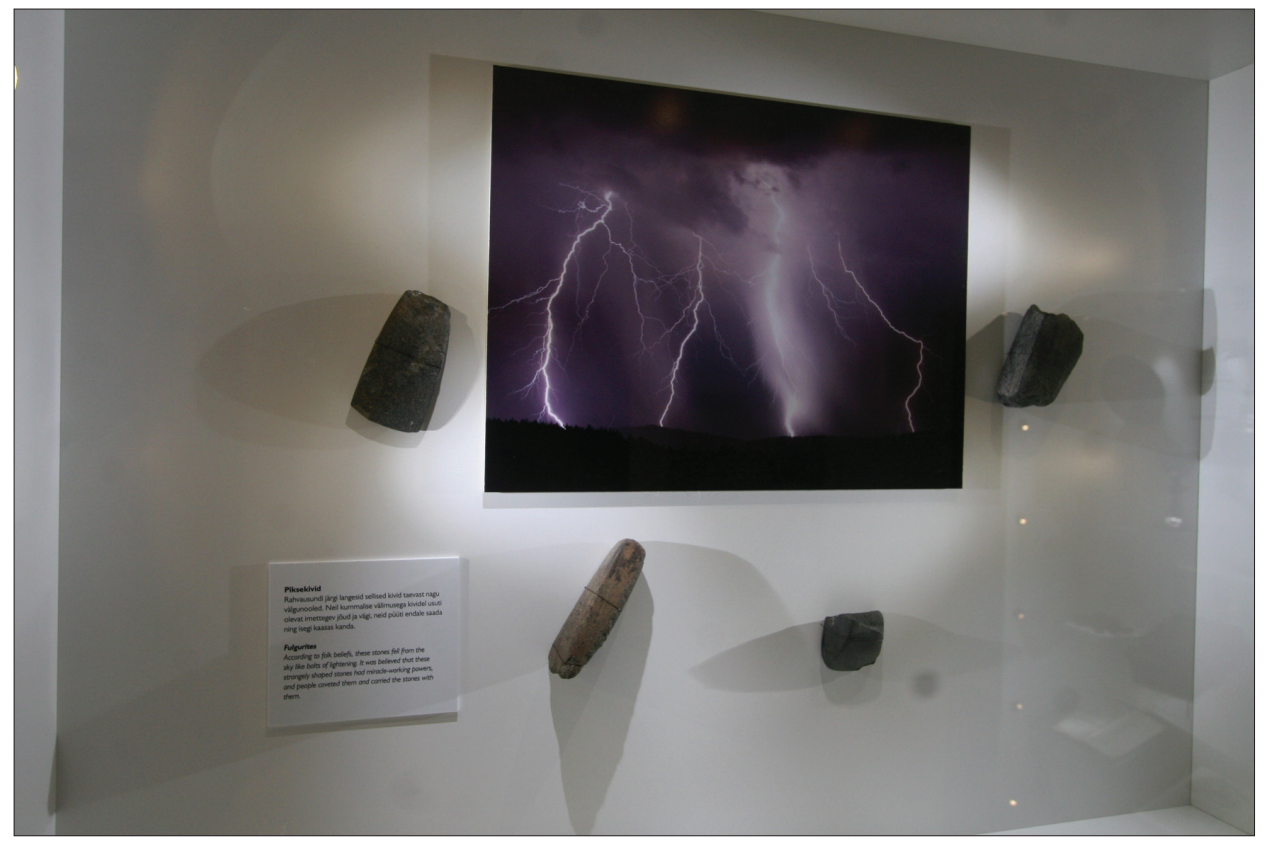

Joonis 8. Piksekividega ekspositsioon Pärnu muuseumis (foto I. Aija).

"pakutava pildi tõetruuduse” (Nõmmela 2009: 143-144). Ekspositsiooni peaeesmärgid osutavad, et nõiduse või maagiaga seotud esemetele seal ruumi ei olnud.

Nõukogudeaegne museoloogia keskendus jätkuvalt majandusviisiga seotud küsimustele, uue teemana tuli sisse kaasaja uurimine (kolhoosielu, kaasaegne etnograafiline küla) ning ühes sellega ka vaimukultuur; kahjuks on kogumisretkede tulemused peaaegu tervikuna analüüsimata ja avaldamata (vt Konksi 2009: 320). Muuseumiekspositsioonidel oli jätkuvalt pedagoogiline roll, kuid usuosa kujundas selles teaduslik ateism. Lähtuvalt valitsevast evolutsionistlikust skeemist "maagia-religioon-teadus" esitati ka vaimuelu peamiselt kas kiviaegsete küttide või võõrvõimu rõhumise katoliiklikus kontekstis. Kasutati laiu ja üldiseid tõlgendusi: "Muistsed inimesed, olles võimetud neile mõistmatute loodusjõudude ees, pidasid neid salapärasteks ja üleloomulikeks. Loodusjõududele ohverdati, neid püüti mitmesuguste austusavalduste ja meelitustega mõjutada" (Pajos \& Landberg 1960: 13). "Usundiliste tõekspidamiste tekkimisest kõnelevad väikesed loomakujukesed vitriinis [---] Taolised loomakujukesed olid seotud küttidele jahiõnne tagamise uskumustega, ent samuti võisid need olla ka totemistlikud sümbolid" (samas: 11). "Ehete-amulettidena kandsid tolle aja inimesed kaelas metsloomade kihvu, milledest näemegi metssea ja karu kihvu, 
mis on varustatud aukudega ..." (samas: 15). Hilisematel perioodidel esines religioon aga juba pigem poliitilises võtmes - kristlik kirik kui võõrvallutajate tööriist Eestis - või seoses kunsti ja arhitektuuriga. Lähimineviku rahvausundit kasutatigi vaid ERMi näitusel alates 1994. aastast, kus tulenevalt muutunud poliitilistest ja ühiskondlikest ideoloogiatest hakati eksponeerima "Eesti oma usku", mille efektseimateks esemeteks olidki viljakushaldjad Peko ja Tõnn. Paradigma muutus toimus Eesti museoloogias alles 1990. aastate lõpus ning alates aastatuhandevahetusest on hakatud näitustel kasutama järjest enam religiooni, mh ka maagiat ja lähimineviku rahvausundit. Näiteks tekitati ERMi püsinäitusele spetsiaalne maagia ja rahvameditsiini teemaline vitriin 2004 . aastal. Hoolimata aga kogudes olevatest arvukatest esemetest kasutati selleski pisikeses vitriinis esemeid, mis nägid küll efektsed välja, kuid millest kõigil ei pruukinudki olla maagia ja ravi-otstarbelist tausta, nagu näiteks ülalmainitud priapus. Enne seda, 2002. aastal toimus Tarbekunsti- ja disainimuuseumis näitus "Nõia nõu", mis samuti kajastas kaasaegseid ja etnograafilisi nõidumis- ja maagiaatribuute. Eraldi piksenooltele ja kaitsemaagiale keskenduv vitriin avati Pärnu Muuseumi uuel püsinäitusel 2012. aastal ning nõiaprotsesse käsitleb ka 2016. aastal avatud uus ERMi püsiekspositsioon.

\section{Arutelu}

\section{Uurimistaust ja "asjalikud" teadused}

Ilmselt on kasin huvi maagia ainelise poole vastu Eestis tingitud lisaks üldisele filosoofilisele ja teadusloolisele taustale nii arheoloogia kui ka etnograafia kujunemisloost. Mõlemad teadused kujunesid Eestis baltisaksa valgustusliikumise ja 19. sajandi romantismi tulemusel ning mõlema suuna peamiseks eesmärgiks sai maa põlisrahva - eestlaste - mineviku uurimine. Tulenevalt valgustuses käibele läinud seisukohast (Herder 1773) esitab just suuline rahvalooming, rahvalaulud, -jutud jne kunagisi uskumusi ja maailmavaadet. Selle pinnalt kujunes 19. sajandil veelahe ainelise ja vaimse kultuuri uurimisse, kus esimene (arheoloogia, etnograafia) tegeles utilitaarsete teemadega ja teine (folkloristika, usuteadus) uuris vaimset kultuuri. Tänu mõlema suuna erinevatele uurimismeetoditele, allikmaterjalile ja teaduslikele traditsioonidele on see erinevus jäänud püsima tänini ning kasvanud tasemele, kus erinevate distsipliinide uurimusi ja järeldusi ongi raske kokku viia.

Arheoloogia keskendus 19. sajandil ja 20. sajandi algul peamiselt kalmete uurimisele, neile järgnesid peagi ka linnused, harvem asulakohad. Hoolimata kalmete tihedast seosest religiooniga on enamik kalmete kohta pakutud 
tõlgendusi ikkagi utilitaarsed, selgitades, milliseid riideid inimesed kandsid, milliste ripatsitega ennast ehtisid ning milliseid tööriistu ja relvi kasutasid. Enam tähendusi otsivate küsimustega - miks on ripatsitel selline kuju, miks on relvad ja tööriistad hauas jne - ei tegeletud üldse või jäädi järeldustes üldiste konstateeringute tasemele, nentides, et tegemist on hauapanustega. Huvitav on siinkohal, et otseselt religiooniga seotud muististe, nt pärimuslike pühapaikadega ei tegeletud üldse ja pikka aega oligi ainsaks arheoloogiliselt uuritud pühakohaks Kreutzwaldi ja Neusi uuritud Viljandi Uduallikas (Kreutzwald \& Neus 1854). Väga selgelt jätkus selline traditsioon 20. sajandi algul, kui vastloodud Eesti Vabariigi arheoloogia kaheks oluliseks teemaks muutus kiviaegne asustus ning hilisrauaaegsed linnused - esimene, sest sellega uuriti maa pikka ajalugu, teine aga võimaldas luua pildi kuulsusrikkast minevikust. 20. sajandi teisest poolest alates toodi küll religioon ja kaasaegne rahvapärimus teemana arheoloogiaalastesse käsitlustesse süsteemsemalt sisse (Lõugas 1996; Valk 2006 ja sealviidatu), kuid teoreetilise ja metodoloogilise tausta puudumise tõttu on tihti võetud pärimust otsese allikana, millele otsiti arheoloogilist tõestust või näidet.

Üsna samalaadsed on olnud arengud ka Eesti etnograafias, teises valdkonnas, mis võiks huvi tunda maagia ainelise poole vastu. Ka seal keskenduti sellele, mida peeti eestlaste kui rahva uurimise huvides oluliseks. Keskseks kujunes seisukoht, et tegemist on agraarse ühiskonnaga ja põhiliselt uuritigi maaviljelust, arhitektuuri, rahvariideid, käsitööd jmt. Religioonile jagus sellises lähenemisviisis kohta vaid juhuslikes kõrvalepõigetes. Nagu arheoloogias, olid ka etnograafias mõned üldtunnustatud seisukohad, mida kasutati, kuid otseselt ei saanud neist uurimisobjekte, nagu nt ornamendis kasutatud sümbolid, peremärgid jne, mida seostati maagilise kaitse taotlemisega. Seega on mõlemad ainelist kultuuri uurivad suunad keskendunud pigem ratsionaalsetele ja utilitaarsetele teemadele, kus oluliseks on peetud tõestatavust ja tõsiseltvõetavust.

\section{Ratsionaalsus kui valitsev filosoofia ja kogumispoliitika}

Michel Foucault on välja toonud, et mõisted tõde, mõistlik, ratsionaalne jne on ajastuspetsiifilised (Foucault 1980: 257). Taksonoomiate loomine antiik- ja keskajal, kuriositeedikambrite kollektsioonide kujunemine valgustusajastul ning ka hilisemad kogumisaktsioonid on oma ajastus olnud selgelt ratsionaalselt põhjendatud (Hooper-Greenhill 1992). Ratsionaalsuse kultuuri-(ja aja-)spetsiifilisust on analüüsitud mitmetes artiklites, nt spetsiifilisest maagia ratsionaalsusest (Jarvie \& Agassi 1970; Kieckhefer 1994) või ratsionaalsuse küsimusest arheoloogilises minevikus ajas võõra "teise” puhul (Brück 1999; Garrow 2012). Nii oli ka 
muuseumikogude kujunemisel 19. sajandil ja suurel osal 20. sajandist aluseks sel hetkel kehtiv “õige” lähenemine sellele, mis oli kogumis- ja eksponeerimisväärne ehk mille kogumine oli ratsionaalselt põhjendatav. On välja toodud, et kõige suurem roll selles, millised esemed ja miks muuseumisse on jõudnud, lasub ühiskonnas (sh muuseumitöötajate hulgas) valitseval kujutelmade, hinnangute ja ajaloonägemuste kogumil, mis väärtustab teatud esemeid muuseumi jaoks (Pärdi 1993: 52). Kogumise kõrgaegadel oli valitseva hinnangutepaketi peamine märksõna teaduslikkuse taotlus. Oli ju ERMi esimeste püsinäituste üks peamisi ideoloogilisi eesmärke rahva harimiseks minevikust tõetruu pildi loomine, selle aluseks omakorda oli teaduslikult (süstemaatiliselt) korraldatud (väljapandud) materjal. Naiivratsionaalne lähenemine õpetas, et esemed on tehtud mingit (üht) kindlat utilitaarset või mitteutilitaarset funktsiooni silmas pidades, nt reha riisumiseks, lusikas söömiseks, sõel sõelumiseks jne. Mitteutilitaarset eesmärki peeti omaseks amulettidele ja ripatsitele. Sellist ühefunktsioonilisust on peetud silmas nii arheoloogiliste leiunimekirjade koostamisel kui ka muuseumikatalooge luues. Selge utilitaarse funktsiooniga eseme kaasnevaid sümbolistlikke tähendusi, eriti kui need tulenevad maagilistest narratiividest, on seega alati keerukam ja spekulatiivsem uurida, ent enamasti ei ole peetud seda piisavalt teaduslikukski. Heaks näiteks selle kohta on piksenooltena ERMi kogudesse jõudnud kivikirved, mis deponeeriti aga kiviaegsete tööriistadena edasi arheoloogiakogudesse. Laiemas mõttes tervemõistuslikku ratsionalismi ja teaduslikkuse taotlemist võib 20. sajandil näha nii esemete kogumis- kui uurimispoliitikas (tõlgendustes, sh ka eksponeerimispoliitikas, mis samuti tugines teadlaste tõlgendustele). See on olnud peapõhjus, miks maagilisi esemeid on kogutud vähe ja eksponeeritud puudulikult, miks tõlgendused on ettevaatlikud ja üldistavad, lausa naiivsed või koguni ignoreerivad. Tõenäoliselt on tegemist ka omalaadse ringkäendusega, kus akadeemiliste diskussioonide vähesus on tinginud maagiliste esemete vähese kogumise ja vastupidi. Nii Pärnu muuseumi kui ka ERMi kogu põhjal võib oletada, et kuna maagilised esemed on väga eripalgelised ja nende põhjal on raske teha üldistavaid järeldusi, siis on just laiema, teadusliku käsitluse puudus üheks põhjuseks, miks neid on näitustel eiratud. Ühelt poolt oli raske pakkuda maagilisele esemele laiemat tausta, teisalt oli ka kõigile selge ületõlgendamise oht.

Nii ongi arheoloogias ja etnograafias valdavalt peetud kogumisväärseks vaid inimese poolt loodud esemeid, sest neile oli analoogiate põhjal kaasajaga lihtsam omistada funktsiooni. Arheoloogias on see üldjuhul tähendanud, et looduslikud ehk inimese poolt töötlemata objektid ei ole olnud kogumisväärsed (vt ka Gilchrist 2008; Gazin-Schwartz 2001), samuti on loomaluud kui looduslikud objektid alati olnud esemeleidude kõrval teisejärgulised ning seepärast ei ole nende leiukonteksti sama püüdlikult dokumenteeritud. Samas leidub ka 
vastupidiseid näiteid nii etnograafilistes kui ka arheoloogilistes esemekogudes. Esimesel juhul on heaks näiteks juba eespool käsitletud kivid, millest nii mõnigi on kogusse võetud ravimaagilise atribuudina. Ka arheoloogiakogudesse on korjatud huvitava välimusega (nt väga siledaid ja lapikuid) kive ja silmatorkavaid fossiile (vt eespool). Väheste tõlgendatute puhul on funktsiooni otsides sageli püütud lähtuda ratsionaalsusest ja leida utilitaarne seletus. Heaks näiteks on peamiselt okasnahksete varrelülide fossiilid, mida on enamasti tõlgendatud kui helmeid. Siiski on valmis kasutuskirjelduse puudumisel neid välitöödele järgnevas faasis enamasti eiratud - nii on sageli juhtunud eelkäsitletud siledate ja ümarate kividega. Selliste leidude näitena võib esile tuua ka Eestis haruldased kvartsiidikristallid, mida on leitud ulatuslikult uuritud ja suhteliselt hästi publitseeritud muististelt (Tamula I kalmistu/asulakoht AI 3960: 41; Asva pronksiaegne kindlustatud asula AI 4366: 925; rooma rauaaegsed kivikalmed Kõrendusel (AI 4866: 227) ja Laheperas AI 4976: 83), kuid mida ei ole uurimustes mainitud.

Ka inimese loodud esemete puhul on alati eelistatud utilitaarset funktsiooni. Heaks näiteks "turvalisest" utilitaarsest tõlgendusest on Rattama talu põllult leitud Viljandi muuseumis oleva kiviketta sõna otseses mõttes ühekülgne eksponeerimine (vt Jonuks jt 2010). Tegemist on 1942. aastal Viljandi lähedalt leitud dolokivist $6 \mathrm{~cm}$ diameetriga kivikettaga, mille keskel on auk ning ühel küljel kahe ristripatsi valuvormi jäljed. Nii eksponeeritigi ketast alates 1950. aastatest Viljandi muuseumis kui "valuvormi, mis rikutud hilisema ümbertegemisega värtna kettaks". Kõikide aastakümnete jooksul ei näidatud ekspositsioonis oleva eseme teist külge, mida katavad 11-14 erinevat, Eesti seisukohalt selgelt võõrapärast maagilist sümbolit ja mis ei sobi ei tõlgendusega esemest kui valuvormist ega ka kui värtnakedrast. Tollase materialistliku ideoloogiaga sobis paremini asjaliku funktsionaalsuse ja mitte unustusse määratud ebausu rõhutamine, hoolimata sellest, et värtnakedrana ei ole seda ketast ilmselt kunagi kasutatud.

Nagu mainitud, on maagilised esemed kogudesse jõudnud juhuslikult erandlike kuriositeetidena ning süsteemse kogumispoliitikaga tegemist ei ole. Nagu ERMi kogu puhul ilmne, on süstemaatilisemalt esindatud just ravimaagia kogu. Lisaks ERMile võib ravimaagia kogumist jälgida ka mujal, nt Põltsamaa Muuseumi Ühing on oma üleskutses annetada muuseumile esemeid, maininud eraldi just arstimisriistu nagu kupuravi, aadrirauad, kõrvakivid, paiserahad jne (Piisang \& Tänav 2007: 207). Just viimase üleskutse puhul tuleb ilmselt esile ka põhjus, miks raviasjad kõige enam esindatud on - paiserahad ja kõrvakivid on siis, 1930. aastail, loetletud kõrvuti kupuravi ja aadriraudadega, kuigi nimekirjas esimesed esindavad meie mõistes maagilist ravikäitumist selgemalt kui kaks viimast. Kogumise ajal oli aga kõigi puhul tegemist ratsionaalsete 

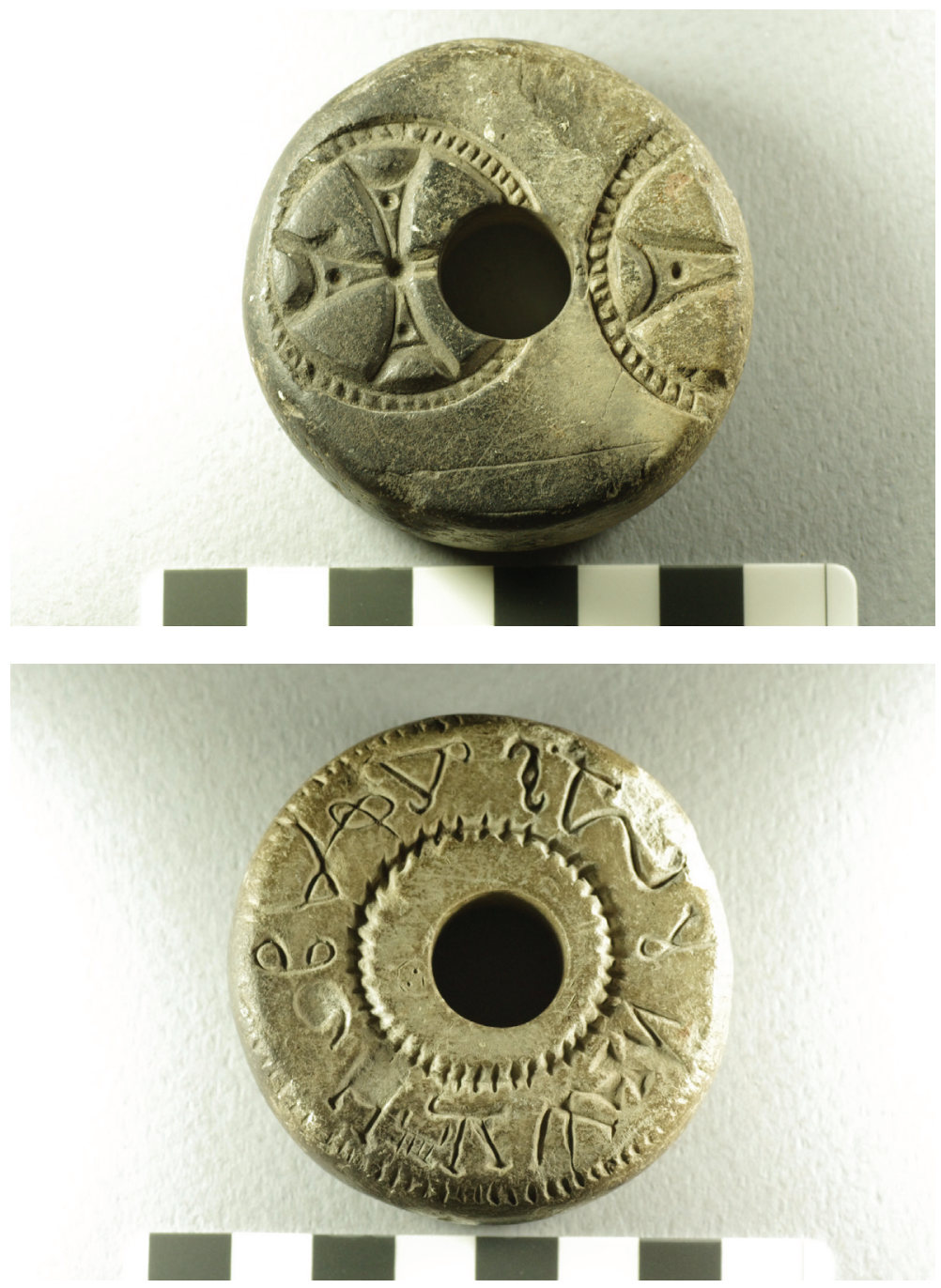

Joonis 9. Kiviketas Rattama talu maadelt. Üleval "valuvorm, mis rikutud hilisema ümbertegemisega värtna kettaks". All sama eseme ekspositsioonis varjatud külg koos sümbolitega (VM 4339).

käibel olevate ravivõtetega. 20. sajandi keskpaiga kogumisloogika järgi koosneb rahvameditsiin kahest osast: 1) usundiline pool, mis kuulub puhtalt rahvaluule hulka; 2) rahva mällu põlvkondade vältel saadud kogemused, millest arstid on leidnud tõhusaid ravimeid. Neist vaid teine oli ratsionaalset ja teaduslikku maailmapilti arvestades kogumisväärne (Kõivupuu 2008: 372; Tupits 2009: 81 
ja seal viidatu). Tänu selgele utilitaarsele funktsioonile erinevaid ravikive ka koguti, samas kui muud maagia valdkonnad (heaolu taotlus, kahjustav nõidus jne), mida esineb pärimuses, on muuseumikogudes esindatud juhuslikult. Selles kontekstis torkabki erandlikuna silma amatöörist minevikuhuvilise, kuid ametilt arsti Martin Bolzi kogumistöö Pärnu ja Viljandi ümbruses. Kuivõrd ta oli teaduses amatöör, ei kammitsenud teda ajastule omased teaduslikud meetodid ja maailmavaated. Tema arsti taust aga soosis nähtavasti huvi rahvameditsiini vastu, mistõttu on ta üles kirjutanud ka ravi- ja piksekividega seotud pärimust, samuti ka üldisemat heaolutaotlust.

Võib tunduda kummaline, et kuigi folkloristid on maagiat ja loitse Eestis mitte üksnes kogunud, vaid ka intensiivselt uurinud (Kõiva 2011; Kõivupuu 2013; Hiiemäe 2012), ei ole maagia ainelist poolt puudutatud peaaegu üldse või on seda esile toodud vaid illustratiivsete näidetena. Pärimuslikes allikates mainitud maagilised esemed on looduslikud (nt erilise kujuga loomaluud, veidrad puuoksad, erinevate loomade hambad, küüned, karvad ja ussipead, elavhõbedaga täidetud pihlakas, kaarnakivi jne) või igapäevased käepärased esemed (toiduained, nt sool, naelad, mündid, riideesemed jne) (Hiiemäe 2012: $84 \mathrm{jj}$ ). See on muutnud keerukaks nii maagiliste esemete kogumise kui ka süstematiseerimise. Looduslike ja igapäevaste esemete, ehkki ravi- või kaitserituaalis kasutatud, muuseumile kogumine oli raskendatud seetõttu, et neid ei osanud kogujad küsida ega annetajad anda, osaliselt võidi neid veel rituaalides kasutada. Lisaks on rahvameditsiini puhul välja toodud, et seda ei olnud tihti lihtne koguda, sest rahvameditsiini kui "niisuguseid asju” peeti mõnel juhul mitteväärikaks teadmiseks (Tupits 2009: 69). Kataloogimise keerukust näitab aga maagiapärimusega esemete leidumine üle terve ERMi muuseumikogu, nii ravimaagia aga ka ehete jt esemete all. Nii ei ole enam võimalik jälgida nende kunagist maagilist kasutust, mis muudab ühelt poolt raskeks ülevaate saamise, teisalt aga illustreerib hästi ka seda, millises keerulises olukorras oli muuseumitöötaja, kes pidi kataloogi looma. Erinevalt paljudest teistest maadest puuduvad Eesti muuseumikogudes spetsiaalselt maagilisteks toiminguteks ja nõiduseks valmistatud esemed, nt tüüpilised õnnetoovad amuletid, nõiapudelid, loitsutahvlid jms. "Kõrgmaagiaga" seonduvad nõiapudelid, keerukad märkidesüsteemid jne on seotud ühtaegu kesk- ning varauusaegse hariduse ja teadusega, mh ka maagiaõpetustega. Sellised suunad ei jõudnud Eestis aga ülikoolist väljapoole, ja nii ammutas siinne maagia oma üleloomuliku jõu traditsioonilistest loodusobjektidest, kus maagiline vägi tuleb pigem nende füüsilistest (ainele omastest, looduslikest) omadustest (nt pihlakas, raud, hõbe jne). Nii on ka kahjustava maagia ja nõidusega seotud esemed, mis mujal Euroopas on tüüpiliselt spetsiaalselt sellisteks toiminguteks valmistatud, Eestis enamasti looduslikku päritolu. Näiteid võib leida pärimusest ${ }^{3}$ ning ajalehetea- 
detest (Sakala teade kuivatatud loomaosadest ${ }^{4}$, Postimehe teade nõianukust $^{5}$ ), nõiaprotsesside ülekirjutustest ${ }^{6}$ kui ka üksikutest leitud esemetest, nt Tartu lähedalt põllult leitud oksapuntrast valmistatud kratt (ERM A291:503).

Tulenevalt maagiliste esemete ambivalentsusest ja tõlgenduste otsesest sõltuvusest narratiivist ei ole maagia ainelist külge ilmselt peetud ka võimalikuks eraldi teemana uurida. Selle heaks näiteks on 1980. aastail korraldatud folkloristikaekspeditsioon Saaremaal, mille käigus uuriti rahvaarste ja nende tegevusi. Selle käigus peeti aga väärtuslikuks üleskirjutatud narratiivi ja rituaalide kirjeldusi, mitte aga esemeid, millega rahvaarstide rituaalid läbi viidi. Nii jäetigi kogumata piksekive ja muid maagilise tähendusega esemeid, mida küll kogujatele pakuti, kuid akadeemilises diskursuses ei väärtustatud (M. Kõiva suuliselt). Ilmselgelt oli selle põhjuseks usundi ja maagia uurimine narratiivipõhiselt, kuhu esemed ei mahtunud. Paljuski tulenevalt sellistest arengutest on arvatavasti ka muuseumites välditud terminit "maagia", mis omakorda mõjutab kogumistööd.

\section{Kokkuvõtteks}

Mõneti on märkimisväärne, kui vähe maagiliste talitustega seotud esemeid Eesti muuseumite kogudes leidub. Võib öelda, et maagiliste esemete vähesus Eesti muuseumikogudes on seotud mitme fenomeniga. Üks põhjus on kindlasti see, et 19. sajandi muuseumiseltside ümber kujunenud kogud moodustusid juhuslikult, hinnates esemete vanust ja kunstilist või materiaalset väärtust. Kaasaegsete või lähimineviku esemete süstemaatiline kogumine algas alles ERMi ja tarbeesemete kogumisega. Alanud kogumistööd mõjutas aga peaasjalikult kehtiv rahvuslik ideoloogia - muuseumisse koguti seda, mida väärtustati ja mida teati väärtustada. Seega langes põhirõhk "eestluse" või kohaliku identiteedi kogumisele ning üldises diskursuses põlastusväärsele ebausule ei saanud osaks sellist väärtustamist, mis oleks loonud selle kogumiseks vajaliku keskkonna. Teiseks on maagiliste esemete vähese kogumise põhjuseks olnud asjaolu, et maagia oli ja on suuresti verbaalne või rituaalne tegevus ja mõnede maagiliste rituaalide jaoks ei kasutatudki mingit spetsiaalset eset. Ka olid maa-

gilistes tegevustes kasutatud esemed needsamad, mis igapäevaselt käibes, ja kuna neil oli enam rolle kui maagiliseks atribuudiks olemine, ei ole neid eraldi ka kogujatele annetatud, või on need kogutuna kataloogitud igapäevaesemete alla. Maagia ja ebausu äratundmine on laiema maailmavaate küsimus. Kuni seda ei ole eraldi arutatud (kirjanduses?) või koolis õpitud, ei saa kasutajad näiteks ravirituaalides kasutatud esemeid maagilisteks pidada - neid kasutati rahvapärases ravis, mis veel 20. sajandi algul koosnes paljuski sõnalistest 
loitsudest, ravimtaimedega ravimisest ning mingis osas ka esemelisest ravist. Kolmandaks võidi paljusid esemeid, eriti rahvameditsiiniga seotud atribuute, 20. sajandi esimestel kümnenditel veel aktiivselt kasutada ega tahetud seetõttu ära anda. 1920. aastail ette võetud rahvameditsiini kogumisretkede allikmaterjal kõneleb samuti sellest, et rahvameditsiiniga seonduvat oli keeruline koguda, sest raviprotseduure ja ravivahendeid hoiti salajas (Tupits 2010: 22 ja seal viidatud). On oletatud, et veel 1920.-30. aastail oli maal elavatel eestlastel küllalt raske pääseda kvalifitseeritud arsti juurde, samas leidus hea tähelepanuvõimega ning mõningase arstimisoskusega inimesi, kes oskasid esimest valuhoogu leevendada ning teadsid rohtu külmetuse ja venituse vastu, pea igas peres. Näiteks roosi ja rästikuhammustuse ravi kuulus 20. sajandi keskel veel külatarga kompetentsi, samuti kurjast silmast, külmetamisest või ehmumisest põhjustatud tervisehädad (Kõivupuu 2008: 375).

Selgelt mõjutasid kogumistööd ka juba ekspositsioonides olevad esemed mida oli, seda koguti juurde, nt setude pühasekapid või õigeusu ikoonid. Seda illustreerib hästi 1930. aastail ERMi saadetud ilmselt koralli fossiil, mille kaaskiri ütleb: "Saatsin Teile pisikeses postpakis ühes käesoleva kirjaga teele, ühe tüki kivistunud kärge. Ei tea küll ise, kas sellel on midagi tähtsat või väärtuslikku, kuid olen kord ise muuseumi külastanud ja kui õieti mäletan, siis nägin vist ka niisugusid kivistunud kärjetükikesi” (Korj rmt 629: 12). Kuigi fossiili kasutamist kirjeldatud ei ole, on korjamisraamatus eseme otstarbe lahtrisse märgitud "arvatavasti arstimisekivi", mis illustreerib hästi ka ERMi toonaste kogujate/vastuvõtjate maailmapilti. Siiski on fossiil hiljem kogust välja arvatud.

Nagu öeldud, takistas kogumistööd osaliselt ka asjaolu, et maagiliste rituaalide läbiviimiseks sobisid tavalised igapäevased esemed ning seetõttu ei “õpitud” maagilisi esemeid ära tundma. Nii ongi juhtunud, et ainelise kultuuri uurimisel on maagia teema käsitlemist leidnud harva ning teoreetiliste ja metodoloogiliste taustauurimuste vähesuse tõttu on tegemist mõistega, mida on pigem üritatud vältida. Enamasti on Eestis ravi- või apotroopilistes rituaalides kasutatud igapäevaseid esemeid või looduslikke objekte, mis ilma neid saatva narratiivita ei ütlegi midagi maagiliste elementide kohta praktikates. Kõrgmaagia ja keerukamad maagilised õpetused ei ole levinud Eestis ilmselt enne 19. sajandit ning spetsiaalselt maagilisteks tegevusteks mõeldud esemete nappus ei ole muutnud maagiat ka huvitavaks uurimisteemaks.

Hoolimata ratsionaalsusest ja teaduse asjalikust mainest ei ole uurijad pääsenud mööda maagia teemadest. Tihti on siis lahenduseks valitud funktsionaalne lähenemisviis ja maagilisi esemeid on vaadatud lähtuvalt nende funktsioonist. See seletab ravimaagiliste esemete head esindatust kogudes, aga ühtlasi ka ravimaagiliste rituaalide uuritust. Kuna puudus akadeemiline diskussioon, on maagia tõlgendamisel käibel olnud pigem üldised ja nn tervest 
mõistusest lähtuvad tõlgendused. Samas manduvad need tõlgendused pigem akadeemiliseks naivismiks, mis ei ole põhjendatud argumentide või arutluskäiguga.

Seega ongi maagiat käsitletud harva ning teemat püütakse vältida, kuna materjali ambivalentsusest tulenevalt ei näi maagia olevat teaduslik uurimisteema. Sellisest lähenemisest tulenevalt on ka maagiliste esemete kataloogimine muuseumites keeruline - teaduskäsitluste puudumise tõttu on tihti otsustatud "kõhutunde" abil, ja nii on saanud maagilise tausta endale ka esemed, millel seda tegelikult kunagi ei ole olnud. Ainsaks lahenduseks saab siin soovitada süstemaatilisemaid käsitlusi nii kõrg- kui igapäeva maagia kohta, et luua laialt kasutatav ja argumenteeritud teoreetiline baas.

\section{Tänusõnad}

Autorid tänavad abi eest artikli ettevalmistamisel Eesti Rahva Muuseumi, Pärnu Muuseumi, Tarbekunsti- ja Disainimuuseumi töötajaid, Ester Orast artikli esialgse versiooni kommenteerimise eest ning Oive Tinni Eesti Rahva Muuseumi rahvameditsiini kogus olevate fossiilide määramise eest. Artikli valmimist on toetanud uurimisgrandid IUT 20-7 ja IUT 22-5 ja Eesti-uuringute Tippkeskus.

\section{Kommentaarid}

1 Narritsa, naari või naaritsa kivi oli ravivahend nähtavasti paisete arstimiseks.

2 Vt kommentaar 1.

3 Ühe teate kohaselt tegid nõiad nõidumiseks nutsakaid, mille sisse pandi põlenud tikuotsi, kanasitta, vanu riideräbalaid ja lõngajuppe, kuivanud leivakoorukesi ja muud, seoti punase lõngaga kinni ning seoti nõiutava majapidamise ukse käepideme või lingi külge (KKI, KS < Häädemeeste, Kägiste. M. Mäesalu 1963). Mitmete teadete järgi viitas kahjustavale nõidusele võõraste asjade, näiteks luudade, kasukate, pastlate jm (nt H III 18, 669 (16) < Vigala, Päärdu v.) leidmine oma taluõuelt. Nõidusele osutas ka verise lihatüki leidmine oma valdustest (nt H II 67, 39/40 (1784) < Koeru (1893)) või kanamuna leidmine sepapaja alt (H II 46, 677/8 (4) < Väike-Maarja). Hobuste nõidumiseks oli sõnniku sisse peidetud külimit karvase riidetüki, verise lihatüki, karvade ja hobusehambaga (KKI 46, 325/7 II < Koeru - K. Sõnajalg, s. 1893).

4 "Õudne leid Visaku teel": Palvepäeval, 12. skp. leiti Heimtalis Visaku teelt kott, mis lähemal vaatlemisel ajas leidjal judinad üle selja. Nimelt leidus kotis ussi päid, vabsikakärjed, kärnkonnad ja veel mitmesugused muud putukad. Kõik need õudsed esemed olid kuivatatud olekus.

Pole vist kahtlust, et need kuuluvad kellelegi maa-arstile (Sakala 15.03.1930, lk 3). 
5 Keegi vana taluperemees Heimtali vallast ilmus Viljandi kriminaalpolitseisse imeliku palvega: võetagu vastutusele tema naabri manuline Alide Kiilaspea, vanem naine, kes püüdvat temale teha kurja - nõidumisega. Näitas ette imetaolise asjapuu, 5-6 tolli pikkuse ja umbes sama jämeda pehastanud puutüki, millesse taotud üks roostetanud latinael ja kaks uut sindlinaela ja mille ümber mähitud hõredalt punast ja kollast lõnga ja valge riideriba. Selle viguri oli naine jüripäeva varahommikul visanud vanaperemehe karjalauda ukse ette - nähtavasti soovides loomadele paha (Postimees 28.04.1934, lk 1).

6 Näiteks süüdistati 1632. aastal tuntud nõida Pudelli, kes oli mitmesuguste nõiasõnade ja nõidumisvahenditega (sisselõigetega kepp, hõbekilling, kolm vasktraadist rõngast, punane villane lõngajupp, roheline sammal) palju inimesi aidanud ja kasu saanud (Madar 1987: 135). 1665. aastal peeti kohtuprotsessi Kopso Maye ja tema tütre Ello üle, viimase vanast elukohast leiti kott, mis oli täis inimeste juukseid, loomakarvu ja rukkililleõisi (Kahk 1987: 147).

\section{Käsikirjalised allikad}

Eesti Rahva Muuseumi korjamisraamatud (käsikirjad ERMi arhiivis):

Korj rmt 83. Leopold Kenni ja Hans Kurvitsi korjandus Audru kih suvel 1912.

Korj rmt 629. Eesti Rahva Muuseumi saadetud materjalid 1937. aastal.

I Kuusalu asulakoht 269-k 1980 AI 5099: 1-544. Leiud. (Käsikiri Muinsuskaitseameti arhiivis.)

Haak, Arvi 2001. Aruanne arheoloogilistest kaevamistest Viljandi ordulinnusel 30. maist 8. juunini 2000. aastal. (Käsikiri Tartu Ülikooli arheoloogia arhiivis.)

Kustin A (1963a). Aruanne Valjala maalinna arheoloogilistest kaevamistest 1962. a. (Käsikiri Tartu Ülikooli arheoloogia arhiivis.)

Kustin A (1963b). Aruanne Paatsa linnuse kaevamisest 1963. a. (Käsikiri Tartu Ülikooli arheoloogia arhiivis.)

Valk, Heiki 2005. Arheoloogilisi andmeid Uusvadast 2005. (Käsikiri Tartu Ülikooli raamatukogus.)

Vassar, Artur 1943. Nurmsi kivikalme Eestis ja tarandkalmete areng. (Käsikiri Tartu Ülikooli raamatukogus.) 


\section{Kirjandus}

Bolz, Martin 1914. Neolithische Steingeräte aus dem Pernau-Fellinschen Kreise und dessen Umgebung. Sitzungsberichte der Altertumforschenden Gesellschaft zu Pernau, vol. 7. Pärnu: Laakmann, lk I-CXVI (http://dspace.ut.ee/handle/10062/22596 - 21. juuli 2017).

Boschung, Dietrich \& Bremmer Jan N. (toim) 2015. The materiality of magic. Paderborn: Wilhelm Fink.

Bremmer, Jan N. 2015. Preface: the materiality of magic. The materiality of magic. Boschung, Dietrich \& Bremmer, Jan N. (toim). Paderborn: Wilhelm Fink, lk 7-19.

Brück, Joanna 1999. Ritual and rationality: some problems of interpretaton in European archaeology. European Journal of Archaeology, 2: 3, lk. 313-344 (doi: 10.1177/146195719900200303, doi: 10.1179/eja.1999.2.3.313).

Eisen, Matthias Johann. 1926. Eesti vana usk. Tartu: Eesti Kirjanduse Selts

Faraone, Christopher A. \& Obbink, Dirk (toim) 1991. Magika Hiera. Ancient Greek magic and religion. New York \& Oxford: Oxford University Press.

Flint, Valerie I. J. 1991. The rise of magic in Early Medieval Europe. Princeton: Princeton University Press.

Foucault, Michel 1980. Power/Knowledge: Selected Interviews and Other Writings 1972-1977. Brighton: Harvester Press.

Garrow, Duncan 2012. Odd deposits and average practice. A critical history of the concept of structured deposition. Archaeological Dialogues 19: 2, lk 85-115 (doi: 10.1017/ S1380203812000141).

Gazin-Schwartz, Amy 2001. Archaeology and folklore of material culture, ritual, and everyday life. International Journal of Historical Archaeology 5: 4, lk. 263-280 (doi: 10.1023/A:1012546516702).

Gilchrist, Roberta 2008. Magic for the dead? The archaeology of magic in Later Medieval burials. Medieval Archaeology 52, lk 119-159 (doi: 10.1179/174581708x335468).

Glück, Eduard 1906. Über Neolithische Funde in der Pernau. Sitzungsberichte der Altertumforschenden Gesellschaft zu Pernau 4, lk 259-318 (http://dspace.ut.ee/ handle/10062/22601?locale-attribute=en -24 . juuli 2017).

Hawkes, Christopher 1954. Archaeological Theory and Method: Some Suggestions from the Old World. American Anthropologist 56: 2, lk 155-168 (http://onlinelibrary.wiley. com/doi/10.1525/aa.1954.56.2.02a00660/pdf - 24. juuli 2017).

Heiberg, Marie \& Veiler, Marta \& Veske, Bertha 2012. Marie Heiberg. Marta Veiler. Bertha Veske. Vanavara kogumisretkedelt 9. Tartu: Eesti Rahva Muuseum.

Herder, Johann Gottfried 1773. Auszug aus einem Briefwechsel über Ossian und die Lieder alter Völker (http://www.uni-due.de/lyriktheorie/texte/1773_herder.html 24. juuli 2017).

Hiiemäe, Reet 2012. Kaitsemaagia eesti rahvausundis. Tallinn: Pegasus. 
Hooper-Greenhill, Eilean 1992. Museums and the shaping of knowledge. London: Routledge.

Hukantaival, Sonja 2007. Hare's feet under a hearth - discussing "ritual" deposits in buildings. Immonen, Visa \& Lempiäinen, Mia \& Rosendahl, Ulrika (toim). Hortus novus: fresh approaches to medieval archaeology in Finland. Archaeologia Medii Aevi Finlandiae 14. Turku: Suomen keskiajan arkeologian seura, lk 66-75.

Hukantaival, Sonja 2009. Horse skulls and "Alder-Horse": the horse as a depositional sacrifice in buildings. Archaeologia Baltica XI, lk 350-356 (http://briai.ku.lt/downloads/ AB/11/11_350-356_Hukantaival.pdf - 24. juuli 2017).

Hurt, Jakob 1888. Paar palwid Eesti ärksamaile poegadele ja tütardele. Olevik 8, 22.02.1888, lk 1 .

Indreko, Richard 1939. Asva linnus-asula. Muistse Eesti linnused. 1936.-1938. a. uurimiste tulemused. Tartu: Õpetatud Eesti Selts, lk 17-52.

Insoll, Timothy (toim) 2011. The Oxford Handbook of Archaeology of Ritual and Religion. Oxford: Oxford University Press.

Jaanits, Lembit 1961. Jooni kiviaja uskumustest. Jansen, Ea (koost). Religiooni ja ateismi ajaloost Eestis. Artiklite kogumik II. Tallinn: Eesti Riiklik Kirjastus, lk 5-70.

Jaanits, Lembit \& Laul, Silvia \& Lõugas, Vello \& Tõnisson, Evald 1982. Eesti esiajalugu. Tallinn: Eesti Raamat.

Jarvie, Ian C. \& Agassi, Joseph 1970. The Problem of the Rationality of Magic. The British Journal of Sociology 18, lk 55-74.

Johanson, Kristiina 2009. The changing meaning of "thunderbolts". Folklore: Electronic Journal of Folklore 42, lk 129-174 (doi: 10.7592/FEJF2009.42.johanson).

Johanson, Kristiina \& Jonuks, Tõnno 2015. Superstition in the house of god? Some Estonian case studies of vernacular practices. Mirator 16: 1, lk 118-140.

Jonuks, Tõnno \& Friedenthal, Meelis \& Haak, Arvi 2010. Värtnakeder, talisman või nõiaese - märkidega kiviketas Viljandimaalt, Rattama talust. Ilusad asjad. Tähelepanuväärseid leide Eesti arheoloogiakogudest. Muinasaja teadus 21, lk 269-286.

Jonuks, Tõnno \& Saage, Ragnar 2015. An antiquarian gift - a collection of Perm animal-style plaquettes in the Estonian History Museum. Baltic Journal of Art History 10, lk 147-165 (doi: 10.12697/BJAH.2015.10.07).

Kahk, Juhan 1987. Ristiusk, teadus ja nõiaprotsessid XVII sajandil. Kivimäe, Jüri (koost). Religiooni ja ateismi ajaloost Eestis. Artiklite kogumik III. Tallinn: Eesti Raamat, lk. 146-171.

Kalle, Raivo \& Sõukand, Renata 2010. Sissevaade eestlaste ravimtaimede tundmise mitmekesisusse. Mäetagused 45, lk 77-94 (doi: 10.7592/MT2010.45.soukalle).

Kieckhefer, Richard 1994. The specific rationality of medieval magic. American Historical Review 99, lk 813-836 (doi: 10.2307/2167771). 
Knüpffer, Georg Martin 1836. Der Berg des Thorapilla: Ein historischer Besuch. Das Inland: Eine Wochenschrift für Liv-, Esth- und Curländische Geschichte, Geographie, Statistik und Litteratur 22.

Konksi, Karin 2009. Etnograafiamuuseumina Nõukogude Eestis 1957-1991. Õunapuu, Piret (koost). Eesti Rahva Muuseumi 100 aastat. Tartu: Eesti Rahva Muuseum, lk 250-355.

Kruusberg, Aleksander 1920. Esiisade enneajalooline õigus. I, Perekond. Tartu: Postimees.

Kuidas nüüdsel ajal nõiutakse. Taluperemees otsis nõiduse vastu kaitset politseist. Postimees nr 114, 28.04.1934, lk 1.

Kuningas, Maire 2014. Ravimise ja nõidumise hõbepreesid. Horisont 1, lk 6-7 (http:// www.horisont.ee/arhiiv-2014/Horisont-1-2014.pdf - 24. juuli 2017).

Kreutzwald, Friedrich Reinhold \& Neus, Alexander Heinrich 1854. Mythische und magische Lieder der Ehsten. Gesammelt und herausgegeben von Fr. Kreutzwald und H. Neus. Peterburi: Buchdrukerei der Kaiserlichen Akademie der Wissenschaften.

Kõiva, Mare 2011. Eesti loitsud. Tallinn: Pegasus.

Kõiva, Mare 2013. Loitsud ja rahvaarstid. Rüütel, Ingrid (toim). Ida-Virumaa rahvakultuurist 2. Rakvere \& Tartu: Viru Instituut, lk 175-196.

Kõiva, Mare 2015. Saatekirjaga rahvaarsti juures. Mäetagused 62, lk 25-54 (doi: 10.7592/ MT2015.62.koiva).

Kõivupuu, Marju 2008. Rahvameditsiin. Viires, Ants \& Vunder, Elle (toim). Eesti rahvakultuur. Tallinn: Eesti Entsüklopeediakirjastus, lk 363-378.

Kõivupuu, Marju 2013. Igal hädal oma arst, igal tõvel ise tohter. Sissevaade Eesti rahvameditsiini. Tallinn: Varrak.

Kõivupuu, Marju 2014. Rahvameditsiin - argipraktikad, uurimisvaldkond, kultuuripärand. Vikerkaar 7-8, lk 109-122.

Luck, Georg 2006. Arcana Mundi. Magic and the occult in the Greek and Roman worlds. A collection of ancient texts. Maryland: John Hopkins University Press.

Lõugas, Vello 1996. Kaali kraatriväljal Phaethonit otsimas. Tallinn: Eesti Entsüklopeediakirjastus.

Madar, Maia 1987. Nõiaprotsessid Eestis XVI sajandist XIX sajandini. Kivimäe, Jüri (koost). Religiooni ja ateismi ajaloost Eestis. Artiklite kogumik III. Tallinn: Eesti Raamat, lk 124-145.

Manning, Chris 2014. Magic, religion and ritual in historical archaeology. Historical archaeology 48: 3, lk 1-9 (doi: 10.1007/BF03376934).

Morris, Brian 2006. Religion and Anthropology: A Critical Introduction. Cambridge: Cambridge University Press.

Nõmmela, Marleen 2010. On creating a realm of memory: the first permanent exhibition of Estonian folk culture in the Estonian National Museum. Ethnologia Fennica 37. Finnish Studies in Ethnology, lk 7-21. 
Nõmmela, Marleen 2009. Rahvusmuuseum rahvusriigis. Eesti rahva muuseum 19201940. Õunapuu, Piret (koost). Eesti Rahva Muuseumi 100 aastat. Tartu: Eesti Rahva Muuseum, lk 105-183.

Ogden, Daniel 2002. Magic, witchcraft, and ghosts in the Greek and Roman worlds: a source book. Oxford: Oxford University Press.

Pajos, Leili \& Landberg, Odette (koost) 1960. Rakvere Rajoonidevaheline Koduloomuuseum. Ekskursioonijuht. Rakvere: Rakvere Rajoonidevaheline Koduloomuuseum.

Piisang, Helen \& Tänav, Rutt 2007. Kuidas Põltsamaale muuseum asutati? Tänav, Rutt (koost). Põltsamaa Muuseumi Toimetised 1, lk 205-219.

Pulst, August 2006. August Pulst. Päewaraamat. Sikka, Toivo \& Tael, Tiina \& Tammaru, Ivi (toim). Vanavara kogumisretkedelt 2. Tartu: Eesti Rahva Muuseum.

Pärdi, Heiki 1993. Muuseumiese etnoloogia uurimisallikana. Pro Ethnologia 1, lk 51-52.

Rahvasteaduslikkude kogude juht 1923. Tartu: Eesti Rahva Muuseum.

Rousselot, Jean-Loup \& Grahammer, Veronika 2004. Beyond Bering. The Russian Colonies in the North Pacific 1741-1867. From the Estonian History Museum in collaboration with the Staatliches Museum für Volkerkunde Munich. Lugano: Galleria Gottardo.

Selirand, Jüri 1974. Eestlaste matmiskombed varafeodaalsete suhete tärkamise perioodil (11.-13. sajand). Tallinn: Eesti Raamat.

Tupits, Ave 2009. Käsitlusi rahvameditsiinist: mõiste kujunemine, kogumis- ja uurimistöö kulg Eestis 20. sajandil. Tartu: Tartu Ülikooli Kirjastus.

Tupits, Ave 2010. MD Voldemar Sumberg and the Folk Medicine Collection of the Estonian Museum of Hygiene from the 1920s and 1930s. Journal of Ethnology and Folkloristics 4: 2, lk 19-30 (http://www.jef.ee/index.php/journal/article/viewFile/53/ pdf_51 - 10. oktoober 2018).

Tvauri, Andres 2006. The establishment of archaeological collections and their current situation. Lang, Valter \& Laneman, Margot (toim). Archaeological research in Estonia: 1865-2005. Estonian Archaeology 1. Tartu: Tartu Ülikooli Kirjastus, lk 225-237.

Valk, Heiki 2004. Võre, sõel ja rist: võreripatsid ja nende tähendus. Aun, Mare \& Jürgenson, Aivar (toim). Setumaa kogumik 2. Uurimusi Setumaa arheoloogiast, ajaloost, rahvakultuurist, rahvaluulest, ajaloost ja geograafiast. Tallinn: Ajaloo Instituut, lk 233-313.

Valk, Heiki 2006. Medieval and Post-Medieval Archaeology of the Native Rural Population. Lang, Valter \& Laneman, Margot (toim). Archaeological research in Estonia: 1865-2005. Estonian Archaeology 1. Tartu: Tartu Ülikooli Kirjastus, lk 205-221.

Oudne leid Visaku teel. Sakala nr 29, 15.03.1930, lk 3.

Õnapuu, Piret 2015. 101 Eesti vana asja. Tallinn: Varrak. 


\title{
Summary \\ "Perhaps used for witchcraft": Magic artefacts in Estonian museum collections
}

\author{
Kristiina Johanson \\ Research Fellow in Archaeology \\ Institute of History and Archaeology, Faculty of Arts and Humanities \\ University of Tartu \\ kristiina.johanson@ut.ee
}

Tõnno Jonuks

Senior Research Fellow

Department of Folkloristics

Estonian Literary Museum

tonno@folklore.ee

Keywords: material studies, materia magica, magic artefacts, museum collections, rationality

It is quite remarkable that the number of artefacts connected with magical practices in Estonian museums is rather small. It can be said that this scarcity is related to several factors. One of the reasons is the fact that collections that grew around the nineteenthcentury antiquarian societies were formed randomly, and cherished the age and artistic or material value of the artefacts. The systematic collecting of contemporary artefacts or those from the recent past gained impetus only when the Estonian National Museum (ENM) initiated campaigns for collecting everyday items in 1909. The collecting activity started by the ENM was clearly influenced by the official national ideology - the museum collected artefacts that were valued, and items of despicable "superstition" were not part of these. The second reason for the scarcity of magic items is the fact that magic was mostly a verbal and behavioural activity and for some rituals no special artefact was needed. In magical practices everyday items were often used, and while these had more roles than being only magical attributes, they were not donated to the collectors or have been gathered and catalogued as tools or commodities. Recognizing magic is a matter of the worldview. Until it is not discussed in books or taught at schools, the users cannot regard the artefacts used in special healing rituals as magical - these were used in folk medical practices which in the beginning of the twentieth century consisted of some apothecary remedies, verbal spells, and herbal treatment, but to some extent also special artefacts were used. This leads us to the third reason for the scarcity of magic items in collections. Many apotropaic or folk medical artefacts could have been actively used at the beginning of the twentieth century, and people were not eager to donate these to the museums. Obviously displays and artefacts in expositions also influenced collecting - seeing and knowing what the museum valued made common people recognize the same kinds of things. 
A notable feature in the small collection of magical items in Estonian museums is the clear focus on curative magic, leaving other aspects of magical practices represented only by single objects. The folk medical collection of the ENM contains several smooth pebbles and fossils used in healing practices. Similar material (more than 500 items altogether) has been gathered from Estonian archaeological sites. However, this kind of archaeological finds have very rarely been interpreted, although it is clear that folkloric background played a role in collecting these in the first place.

The reasons for the scarce interest in material magic in academic research vary. Firstly, both archaeology and ethnography have tried to appear as scientific and credible disciplines which hardly deal with matters of magic or superstition. The general rational worldview has played a significant role also in the theoretical and methodological background. Nevertheless, religion and magic have been discussed to some extent, and artefacts with a magical background have reached museum collections. However, due to the valid rationalistic worldview, their interpretation has been clearly functioncentred (e.g. the dolostone disk from Rattama), with mostly utilitarian functions in the foreground. This explains the higher representation of curing magic in collections, whereas the use of ear-stones (Bryozoan fossils), for example, clearly involves rational elements like heating the stone and pouring water on it to create curative steam for the ears. The function could also be non-utilitarian, for example, apotropaic amulets have been created for this purpose. If magical interpretations were used, these tended to be general and common-sense, for instance, related to the fear of natural forces. These interpretations often degenerate to academic naivety, and are grounded neither by arguments nor by reasoning. Also, the nature of artefacts used in magical practices in Estonia has played a considerable role in the lack of interest towards material magic. In most cases natural or everyday artefacts have been used, which, without an accompanying narrative, cannot be regarded as magical. High magic and more complicated teachings did not spread outside the University of Tartu in Estonia until the nineteenth century, and the scarcity of artefacts specifically made for magical practices has inhibited magic from becoming an attractive research topic.

Due to the lack of academic studies, the cataloguing of magical artefacts has been complicated: sometimes the artefacts have been ascribed magical meaning that they actually did not have, sometimes their actual magical use has been ignored or hidden behind utilitarian functions. The only solution seems to be the increasing level of systematising studies on different forms of magic, with the purpose of creating a widely used and well-reasoned theoretical discussion. 